\title{
Foraminifera of shallow and very shallow facies from the upper Eocene-lower Oligocene Kazandere Member, Soğucak Formation, Thrace Basin, northwest Turkey
}

\author{
$\begin{array}{lll}\text { E. Sirel T. Ayyıldız A. Deveciler* } & \end{array}$ \\ Ankara University, Engineering Faculty, Department of Geological Engineering \\ 06830, Gölbaşı-Ankara, Turkey \\ Sirel E-Mail: sirel@ankara.edu.tr \\ Ayyıldız E-Mail: ayyildiz@eng.ankara.edu.tr \\ Deveciler E-Mail: adeveci@eng.ankara.edu.tr, alideveciler@gmail.com
}

${ }^{*}$ Corresponding author

A B S T R A C T

The middle-upper Eocene to lower Oligocene Kazandere Limestone Member of the Soğucak Formation is widely represented in the Thrace Basin and rich in shallow-water marine foraminifera. Very shallow-water Priabonian facies described here include Borelis vonderschimitti, Borelis laxispira sp. nov., Chapmanina gassinensis, Chapmanina elongata sp. nov., Pfendericonus globulus sp. nov., Orbitolites minimus, Coscinospira sp. Last occurrences of the aforementioned Priabonian species and first appearances of the shallow-water marine Rupelian species Nummulites fichteli, Nummulites vascus and Operculina complanata define the Eocene-Oligocene boundary in the new Kazandere Member at the northeast Thrace Basin.

KEYWORDS Priabonian-early Oligocene. Kazandere Member. Stratigraphy. Foraminifera. Thrace Basin.

\section{INTRODUCTION}

The main objective of this study is to define the reference section (holostratotype) of the new Kazandere Member of the Soğucak Formation and its parastratotype, in the northeastern Thrace (Fig. 1A-C). These sections were investigated as to their microfacies, taxonomy and biostratigraphy of the shallow/very shallow-water Priabonian foraminifera.

The Thrace region has been geologically investigated since the mid 20th Century. Daci (1951) described middle-late Eocene foraminifera, especially from genus Nummulites LAMARCK in the Küçükçekmece and Çatalca regions, East of Thrace. Akartuna (1953) performed a geological study based on this genus in the same region (Çatalca-Karacaköy). The chronostratigraphic record of foraminifera from this region was improved by Sirel and Gündüz (1976), who were the first to report the existence of marine Oligocene in the Thrace region based on Nummulites.

New insights in the geology of the Thrace Basin were provided by Şengör and Yilmaz (1981) who studied the tectonic evolution of the Tethys in Turkey. Later, Turgut et al. (1991) studied the evolution of the Thrace Basin and its hydrocarbon potential, and Görür and Okay (1996) suggested a fore-arch origin for this basin. 


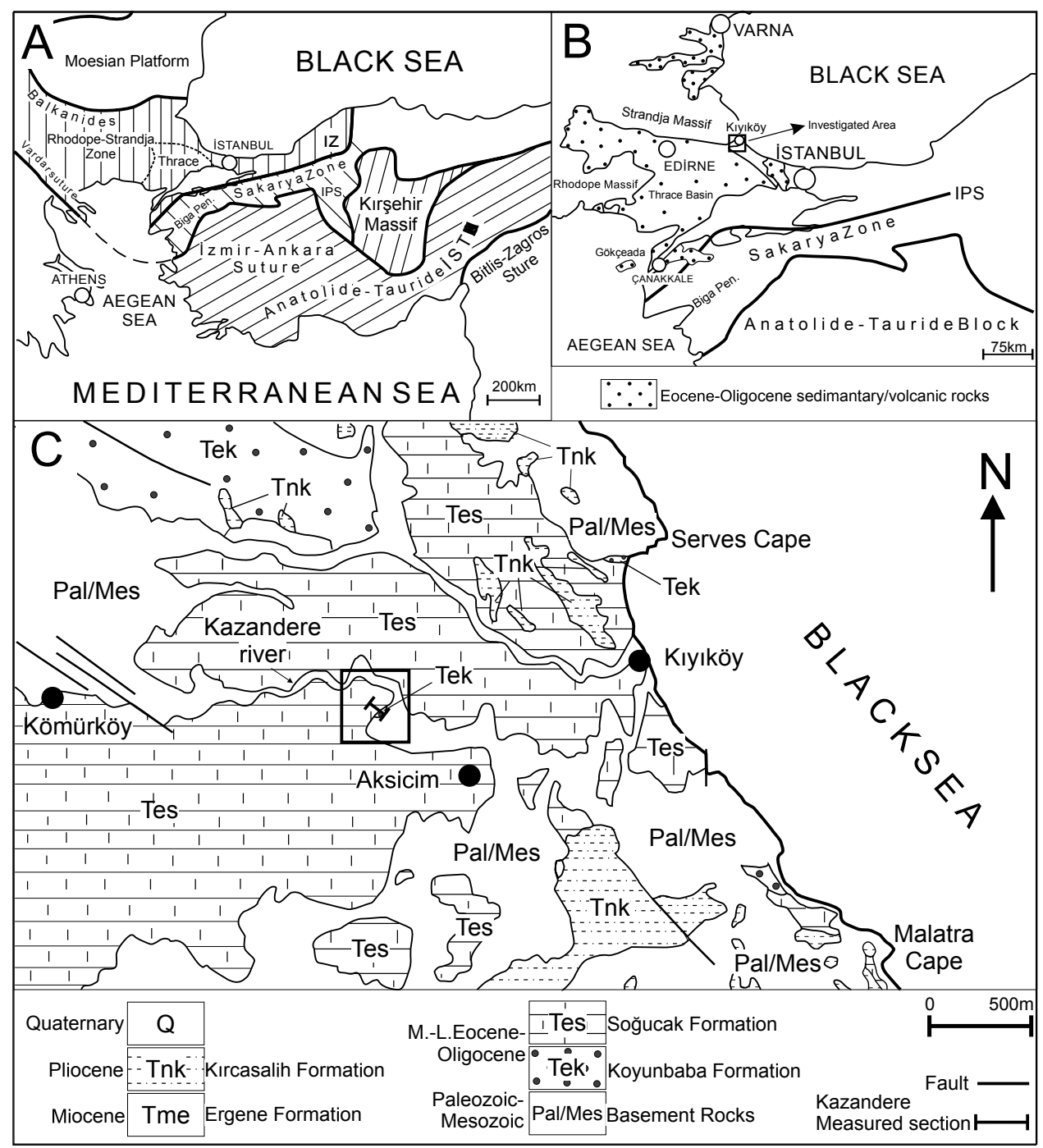

FIGURE 1. A) Tectonic map of the northeastern Mediterranean region showing the major sutures and continental blocks (simplified from Okay and Tüysüz, 1999); IZ: Istanbul Zone; B) Simplified map of the Black Sea-North Aegean region showing the distribution of Eocene-Oligocene sedimentary and/or volcanic rocks and the main tectonic sutures (modified from Okay et al., 2017); C) Geological map of the Kiylköy region and location of the studied section (simplified from Çağlayan and Yutsever, 1998).

As regards the stratigraphy and sedimentology of the Thrace Basin, Varol et al. (2009) studied the carbonates in Bozcaada and Kiyıköy. Okay et al. (2010) identified the basement rocks of the southern Thrace Basin, and studied the lower Eocene series and the upper Eocene olistostromes. Less et al. (2011) studied the larger foraminifera and shallow-marine rocks of the middle-Eocene to lowerOligocene in the North and East of Thrace Basin. Okay et al. (2017) described in Çatalca the connection between the west Black Sea and the Thrace Basin during the late Eocene to the early Oligocene. Recently Okay et al. (2020), Özcan et al. (2020) and Yücel et al. (2020) have investigated the biostratigraphy of foraminifera in the Thrace Basin.

According to the current stratigraphical and paleontological knowledge, very shallow/shallow-water marine rocks containing rich assemblages of larger benthic foraminifera of Bartonian-Priabonian age are widespread in Turkey (Deveciler, 2010; Deveciler, 2014; Less et al., 2011; Özcan et al., 2019; Özcan et al., 2020; Sirel and Gündüz, 1976; Sirel, 2003; Sirel, 2015; Yücel et al., 2020). Nonmarine deposits are abundant after the Bartonian while marine Priabonian and lower Oligocene rocks yielding foraminifera of very shallow-water facies were confined to small areas (Sirel and Acar, 1982; Sirel, 1996; Sirel et al., 2013). This process of progressive marine regression may have been connected with orogenic uplift of the Anatolian region. A similar situation is found all over the Mediterranean region, where shallow and especially very-shallow marine environments with porcellaneous foraminifera such as alveolinids, soritids, peneroplids and miliolids predominate in the Priabonian to lower Oligocene depositional sequences. 
Middle Eocene-Oligocene shallow-water rocks with nummulitids (genera Nummulites, Assilina, Operculina and Heterostegina), orthophragminids and other foraminifera from the Thrace Basin have been studied by Akartuna (1953), Daci (1951), Less et al. (2011), Okay et al. (2017), Okay et al. (2020), Özcan et al. (2020), Yücel et al. (2020) and Sirel and Gündüz (1976). In contrast, the occurrence of very-shallow-water benthic foraminifera in the Priabonian is reported here for the first time and is noteworthy at a regional scale.

Very-shallow-water foraminifera from the same time span are known in other Mediterranean regions. For instance, the Bartonian?-Priabonian species Neoalveolina vonderschimitti was first described and figured from samples from Colli Berici, North Italy, by Schweighauser (1951). Hottinger (1963) reported early Oligocene veryshallow-water foraminifera in southern Spain. Borelis vonderschimitti (SCHWEIGHAUSER) was reported by Drobne and Pavlovec (1979) and Drobne et al. (1985) as an important marker for this environment in the Priabonian of the west side of the Pannonian Basin, North Slovenia.

\section{MATERIALS AND METHODS}

Foraminifera were described with the help of 80 oriented thin sections from limestone samples 16-TA and KZ. Microfacies and fossils were photographed using a Leitz microscope. The suprageneric classification followed the systematics of Loeblich and Tappan (1987). All the studied samples are stored in the Museum of the Department of Geological Engineering, University of Ankara, Turkey.

\section{STRATIGRAPHY}

Very shallow-water marine Priabonian facies and shallow-water lower Oligocene limestone facies with benthic foraminifera were investigated (Fig. 2A-C) in
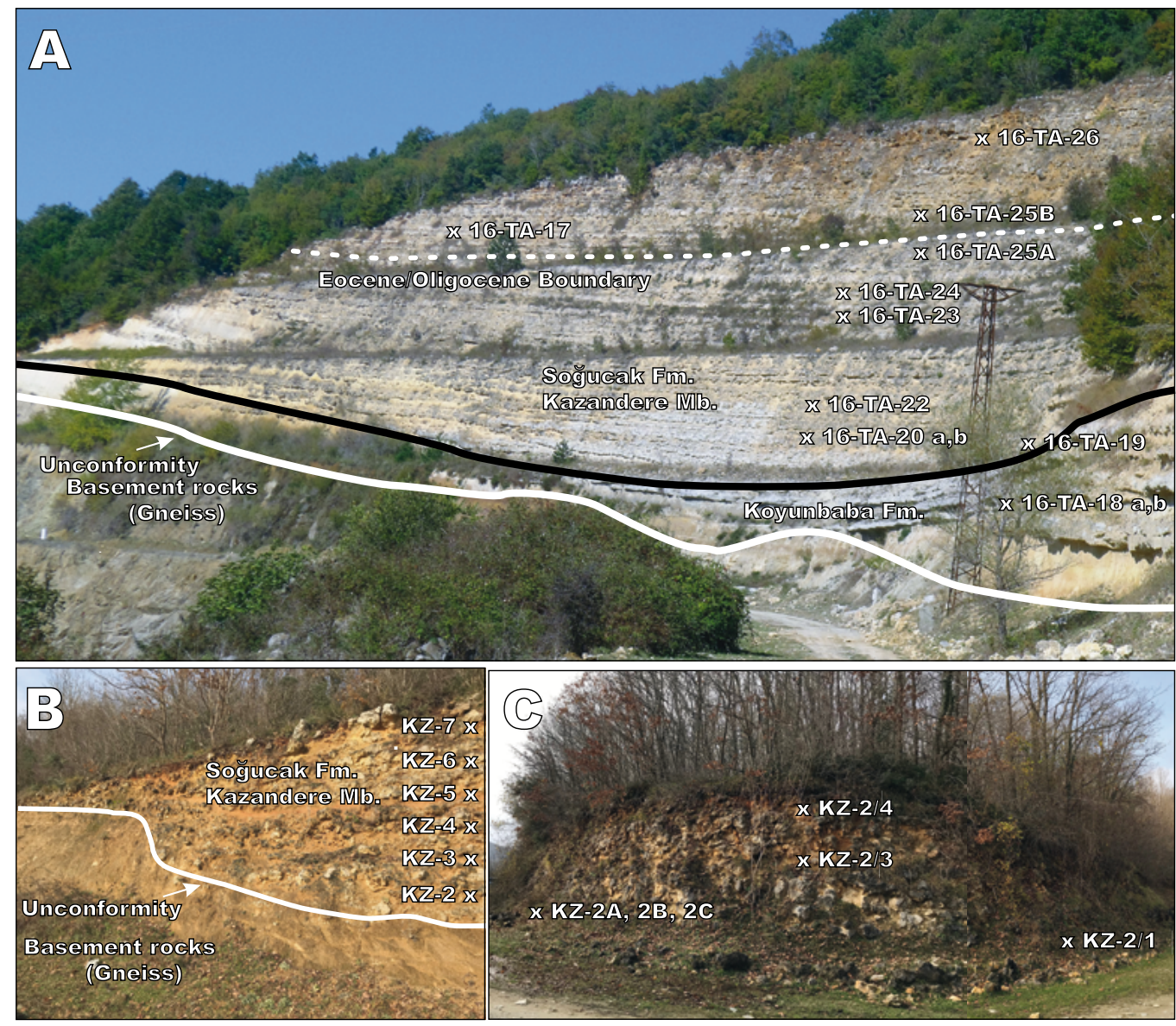

FIGURE 2. A) Field view of the holostratotype of Kazandere Member, near the Kıyıköy town, NE of Kırklareli, northeastern of the Thrace Basin, showing the stratigraphic position of the studied samples, and the overlying and underlying units; B) Field view of the parastratotype section of the Kazandere Member, near the Kıyıköy town, NE of Kırklareli, northeastern of the Thrace Basin, showing the position of Priabonian samples; C) Nodular limestone which corresponds to the base of B showing the position of studied samples. 
northeast Kırklareli, northeast part of the Thrace Basin (Fig. 1C), between the towns of Kıyıköy and Kömürköy.

\section{Lithostratigraphy}

Numerous informal lithostratigraphic units have been proposed in former geological studies of the Thrace Region. Some of them have been certified as formal units by the Stratigraphy Committee of Turkey (see Siyako, 2006). The relevant lithostratigraphic unit in the present study is the Soğucak Formation (Siyako, 2006), to which the new Kazandere Member belongs. The type section of this formation is situated in the Soğucak village (map reference E 19-d2). The lithological features and the foraminiferal content of the Soğucak Formation have been described by Daci (1951), Akartuna (1963), Sirel and Gündüz (1976), Less et al. (2011), Okay et al. (2017, 2020), Özcan et al. (2020) and Yücel et al. (2020) in different areas of the Thrace region. According to Siyako (2006) the Soğucak Formation is mainly composed of shallow-water limestone alternating with marl and sandstone with benthic foraminifera including nummulitids, orthophragminids and other groups. The formation is late Bartonian to early Oligocene in age.

\section{Kazandere Member of the Soğ ucak Formation}

The Kazandere succession (Fig. 2A-C) is defined here as a new member of the Sogucak Formation, and

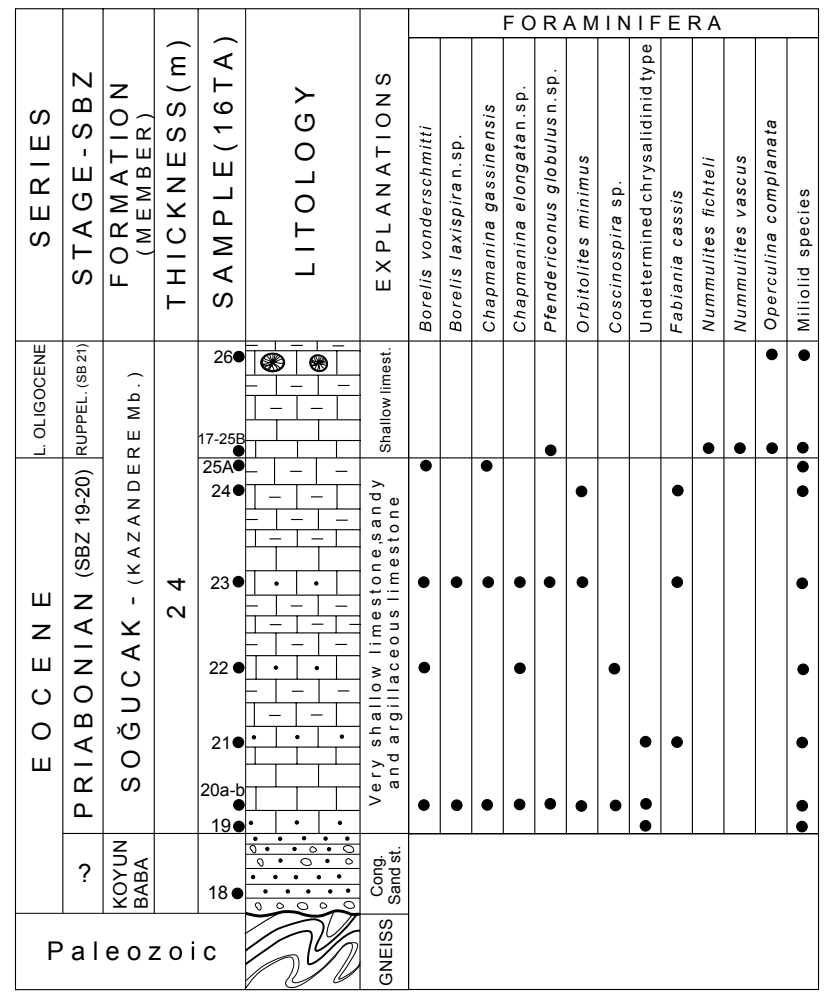

FIGURE 3. Log of the holostratotype (reference section) of the Kazandere Member. the Kazandere section (Fig. 2A) is chosen as its reference section (holostratotype) because of its completeness, accessibility, and foraminiferal content. Other sequences (Fig. 2B, C) located around the Kazandere member are proposed as a parastratotype of the new member.

Type locality. The Kazandere holostratotype (Figs. 2A; 3 ) is situated North of the Kazandere Dam (map reference: E 19-d2); coordinates ( $x=3558824 \mathrm{D}, \mathrm{y}=4607979 \mathrm{~K}, \mathrm{z}=43$ $\mathrm{m}$ ). The parastratotype (Figs. 2B, C; 4) is located at map reference $\mathrm{E} 19-\mathrm{d} 2$, with coordinates $(\mathrm{x}=3558903 \mathrm{D}$ and $\mathrm{y}=$ $4607574 \mathrm{~K}, \mathrm{z}=37 \mathrm{~m})$.

Lower and upper boundaries. The Kazandere Member overlies with conformity the Koyunbaba Formation at the holostratotype (Fig. 2A). However, at the parastratotype the Kazandere member overlies the basement metamorphic rocks of the Paleozoic (Fig. 2B, C). Its upper boundary is unknown in the studied area.

Lithology. The Kazandere Member (Fig. 2A-C) is composed of hard, generally light-brown limestone, less frequently of light-brown nodular limestone. All studied limestone samples (Fig. 2A-C; 3; 4) contain abundant fragments of bivalves (Fig. 5A-E), corals (Fig. 5D, F) and foraminifera as shown in Figures 6-13.

Thickness. $24 \mathrm{~m}$ at the reference section (holostratotype).

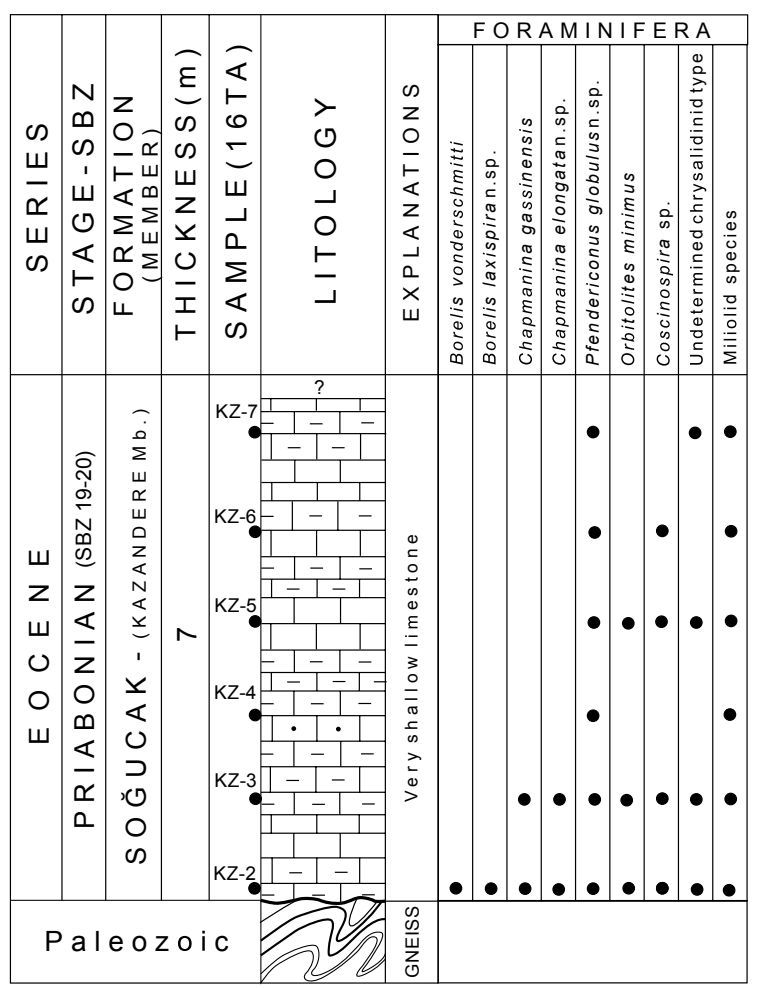

FIGURE 4. Log of the parastratotype of Kazandere Member. 
Foraminiferal content and age. From sample 16 TA-19 to sample 16 TA-25A the limestone is Priabonian in age and contains very shallow-water foraminifera. This contitutes the first report of such assemblages in both the Thrace region and the whole Anatolia. The lithology and the foraminiferal content of samples in holostratotype (Fig. 3) and parastratotype (Fig. 4) are (from bottom to top) as follows:

16-TA-19. Sandy limestone with undetermined chrysalidinids and miliolids (Fig. 5A).

16-TA-20a, b. Limestone with $B$. vonderschimitti, B. laxispira n.sp., C. gassinensis, C. elongata n.sp., P. globulus n.sp., O. minimus, Coscinospira sp., Fabiania. cassis, undetermined chrysalidinids and miliolids (Fig. 7D). The acme zone of $B$. vonderschimitti and B. laxispira n.sp. occurs at this level.

16-TA-21. Sandy limestone with $F$. cassis, undetermined chrysalidinids and miliolids.

16-TA-22. Sandy limestone with $B$. vonderschmitti, $C$. elongata n.sp., Coscinospira sp. and miliolids (Fig. 10A).

16-TA-23. Sandy limestone with $B$. vonderschimitti, B. laxispira n.sp., C. gassinensis, C. elongata n.sp., $P$.
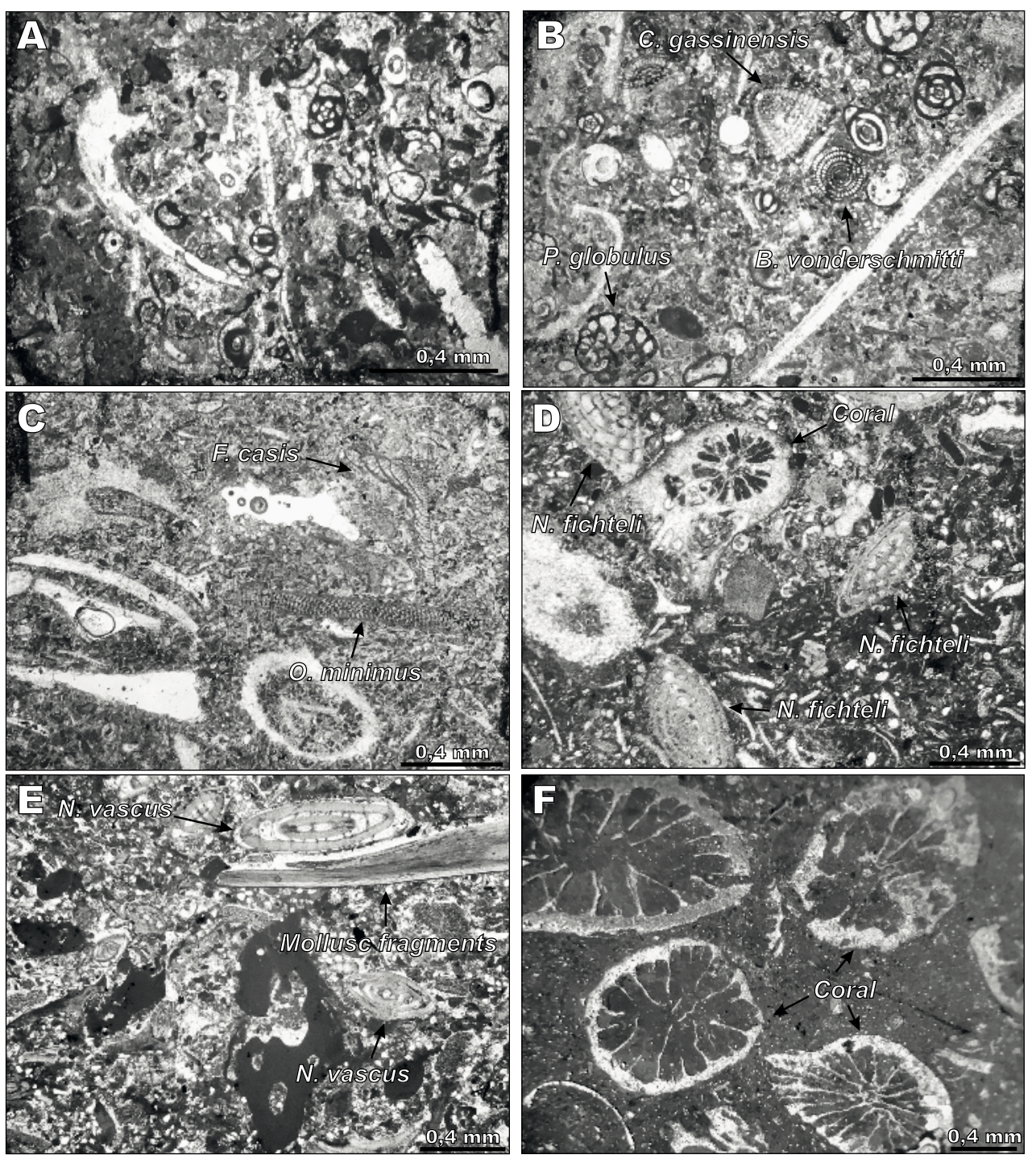

FIGURE 5. Microfacies of the reference section of the Kazandere Member. A) Sandy limestone with very shallow foraminifera, from the base of the Kazandere Member (16-TA-19/2). B) Priabonian sandy limestone with abundant very shallow marine foraminifera such as B.vonderschmitti, C. gassinensis, P. globulus sp. nov. and miliolids (16-TA-23C/8). C) Priabonian argillaceous limestone containing O. minimus, F. cassis and fragments of molluscs (16-TA-24/1). D) Early Oligocene shallow marine limestone with $N$, fichteli, a horizontal section of coral and small fossil fragments (16TA-17/5/3) E) Upper Oligocene limestone with N.vascus, algae and fragments of molluscs (16-TA-17/5). F) Lower Oligocene limestone with corals and algae (16-TA-26). 
globulus n.sp., O. minimus, F. cassis and miliolids (Fig. $5 \mathrm{~B} ; 11 \mathrm{E})$.

16-TA-24. Argillaceous limestone with O. minimus, $F$. cassis and miliolids. This level is the acme zone of $O$. minimus (Fig. 5C).

16-TA-25A. Argillaceous limestone with B.vonderschmitti, C. gassinensis and miliolids of Priabonian age.

16-TA-25B. Limestone representing the boundary between the Priabonian and the early Oligocene. It yields $P$. globulus n.sp. and abundant miliolids.

16-TA-17. Limestone with $N$. fichteli, $N$. vascus and $O$. complanata, deposited in a shallow-water environment of early Oligocene age (Fig. 5D, E; 13D).

16-TA-26. Limestone with corals with rare $O$. complanata of early Oligocene age (Fig. 5F).
Environmental interpretation: In a micropaleontological study performed in the Gulf of Aqaba, the depth distribution of Borelis spp. was reported to be between 5 and $60 \mathrm{~m}$, mainly 20-40m (Reiss and Hottinger, 1984, p. 267, fig. G 42). According to Hottinger (1974, fig. 5), Orbitolites LAMARCK species occur mainly in restricted shelves with normal salinity. The chrysalidinids seem to be restricted to extremely shallow-water deposits (Hottinger and Drobne, 1980 , p. 13, 35). The data available support a very shallowwater (inner ramp) environment for samples 16-TA-19 to $25 \mathrm{~A}$ from the reference section (Figs. 2A; 3) and for samples KZ-2 to 7 from the parastratotype (Figs. 2B-C; 4).

The presence of N. fichteli, N. vascus (Fig. 5E), O. complanata (Fig. 13D) and corals (Fig. 5D, F), in the samples 16-TA-17, $25 \mathrm{~B}$ and 26 suggested a shallow-water marine environment. A similar picture with $N$. fichteli has been introduced from the fore-reef shoal limestone of the lower-middle Oligocene Kirkuk well, North Iraq by Henson (1950b, p. 219, Fig. 6), thus supporting the idea of a shallowwater environment for the top of the newly defined member.

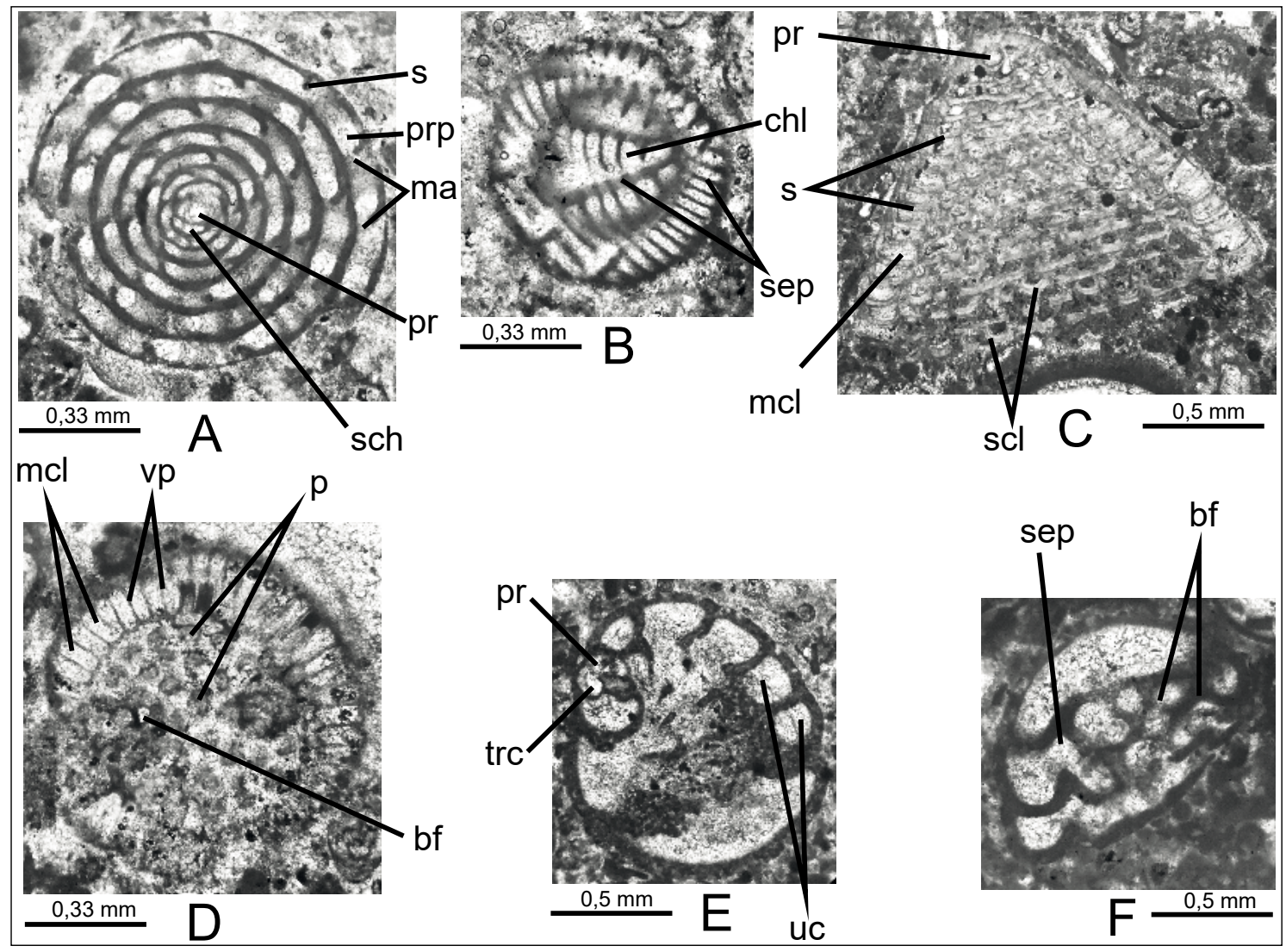

FIGURE 6. Structural elements of Borelis DE MONTFORT, Chapmanina SILVESTRI and Pfendericonus HOTtINGER AND DROBNE from the studied units. A) Borelis laxispira sp. nov., equatorial section (KZ-2/5/2/3). B) Borelis laxispira sp. nov., tangential section (TA-20b/13). C) Chapmanina gassinensis (SILVESTRI), vertical section, (KZ-3/2/9). D) Slightly oblique horizontal section of Chapmanina sp. (TA- 22/7). E) Pfendericonus globulus n.sp., almost vertical section (KZ- 2/2C/1). F) Incomplete horizontal section of Pfendericonus globulus n.sp (KZ- 2/2C/3-1). Abbreviations: (pr) Protoconch, (ma) main aperture, (sch) streptospiral chambers, (prp) preseptal passage, (s) septa, (sep) septula, (cl) chamberlets, (mcl) main chamberlets, (scl) secondary chamberlets, (bf) basal foramina, (p) pillar, (vp) vertical partitions, (trc) trochospiral chambers, (uc) uniserial chambers. 


\section{BIOSTRATIGRAPHY}

Serra-Kiel et al. (1998) and Cahuzac and Poignant (1997) established the shallow-water benthic biozones of the Tethyan Paleocene-Eocene (SBZ 1-20) and of the European Oligo-Miocene (SBZ 21-26). The following SBZs identified in the Kazandere Member are based on those studies.

\section{SBZ 19-20 (Priabonian)}

The first and the last occurrences of $B$. voderschimitti and $C$. gassinensis defined the lower and upper boundaries of this zone, respectively, which correspond to zones SBZ 19-20 of Serra-Kiel et al. (1998). Other species recognized in this interval were B. laxispira n.sp., C. elongata n.sp., P. globulus n.sp., O. minimus, Coscinospira sp. and an undetermined chrysalinid (Fig. 3).

\section{SBZ 21 (early Oligocene)}

The first occurrence of $N$. fichteli and $N$. vascus, define the lower boundary of the SBZ 21 in the Kazandere Member (Figs. 2A; 3). O. complanata (Fig. 13D) occurs rarely in this interval. According to Cahuzac and Poignant (1997, p. 155), the first appearance of $N$. fichteli and $N$. vascus define the lower boundary of SBZ 21.

\section{Eocene-Oligocene boundary}

The boundary between the Eocene and the Oligocene is defined by the last occurrence of the Priabonian foraminifera $B$. voderschimitti, $C$. gassinensis, C. elongata n. sp., $P$. globulus n. sp. and $O$. minimus or by the first appearance of the Oligocene species $N$. fichteli, N. vascus and $O$. complanata (Figs. 2A; 3).

\section{SYSTEMATIC PALEONTOLOGY}

Family: Alveolinidae EHRENBERG, 1839

Genus Borelis DE MONTFORT, 1808

Type species: Borelis melenoides DE MONTFORT, 1808= Nautilus melo FICHTEL AND MOLL, 1798

Description. The test is globular, subglobular, nautiloid, elongated, ovoid and fusiform. The small proloculus is followed by two, may be three whorls of streptospiral chambers, and then divided by planispiral biloculine chambers with numerous chamberlets. Only a preseptal passage, one row of apertural foramen (Fig. 6A) and continuous septula and chamberlets (Fig. 6B) are present (Fig. 6A, B).

Remarks. This genera occurs from the Priabonian to the recent.
Borelis vonderschmitti (SCHWEIGHAUSER, 1951) (Fig. 7A-G) 1951 Neoalveolina vonderschmitti SCHWEIGHAUSER, p. 465-469, text figs. 1-4.

1979 Borelis aff. vonderschmitti (SCHWEIGHAUSER), Drobne, Pavlovec in Frank Drone, fig. 2, pl. 4.

1985 Borelis vonderschmitti (SCHWEIGHAUSER), Drobne et al., p. 87, pl. 1, pl. 3, figs. 4-6.

1998 Borelis vonderschmitti (SCHWEIGHAUSER), Serra-Kiel et al., fig.2.

2010 Borelis vonderschmitti (SCHWEIGHAUSER), Benedetti, Pl. I, figs. 3-4.

Description. The species has a small, almost spherical test (Fig. 7A-G). The equatorial diameter ranges from 0.63 to $0.83 \mathrm{~mm}$ and the axial diameter is $0,63 \mathrm{~mm}-0.83 \mathrm{~mm}$. The small proloculus is followed by one to two rows of streptospiral undivided early chambers (Fig. 7F-G). The following whorls are coiled tightly and divided by numerous narrow chambers (Fig. 7E). The small chamberlets and septula are arranged continuously from one chamber to the next. The chamberlets have an upright elongated oval shape (Fig. 7A-B). The preseptal passage is narrow (Fig. 7E).

Remarks. B. vonderschmitti was first described and figured as $N$. vonderschmitti from the middle Eocene-lower Priabonian of Vicentin (North Italy) by Schweighauser (1951, text figs. 1-4). Later, it was reported from the Priabonian on the west side of the Pannonian Basin (North Yugoslavia) by Drobne and Pavlovec (1979, p. 160, fig. 2, pl. 4, figs. 1, 2). B. vonderschmitti has also been recorded from the Priabonian of the Pannonian Basin, Makole-Ravna gora (North Slovenia) by Drobne et al. (1985).

Distribution. The Priabonian very shallow-water limestone 16-TA- 20a,b (Fig. 2A) records the acmezone of $B$. voderschimitti-B. laxispira n.sp. and other foraminifera, such as $C$. gassinensis, $C$. elongata n.sp., $P$. globulus n. sp., O. minimus, Coscinospira sp., Haymanella sp., an undetermined chrysalinid and numerous species of miliolids. This assemblage belongs to the biozone SBZ 1920 of Serra-Kiel et al. (1998) and is located just below the early Oligocene shallow-water limestone bearing fossils of the N. fichteli and N. vascus zone of Cahuzac and Poignant (1997, p. 155).

\section{Borelis laxispira sp. nov. SİREL AND DEVECILER (Fig. 8A-L)}

1951 Neoalveolina sp., SCHWEIGHAUSER, p. 467, fig. 5.

Origin of name. It refers to the characteristic loosely coiled whorls.

Holotype. Specimen KZ-2/2C/2 (axial section) in Figure 8L. 

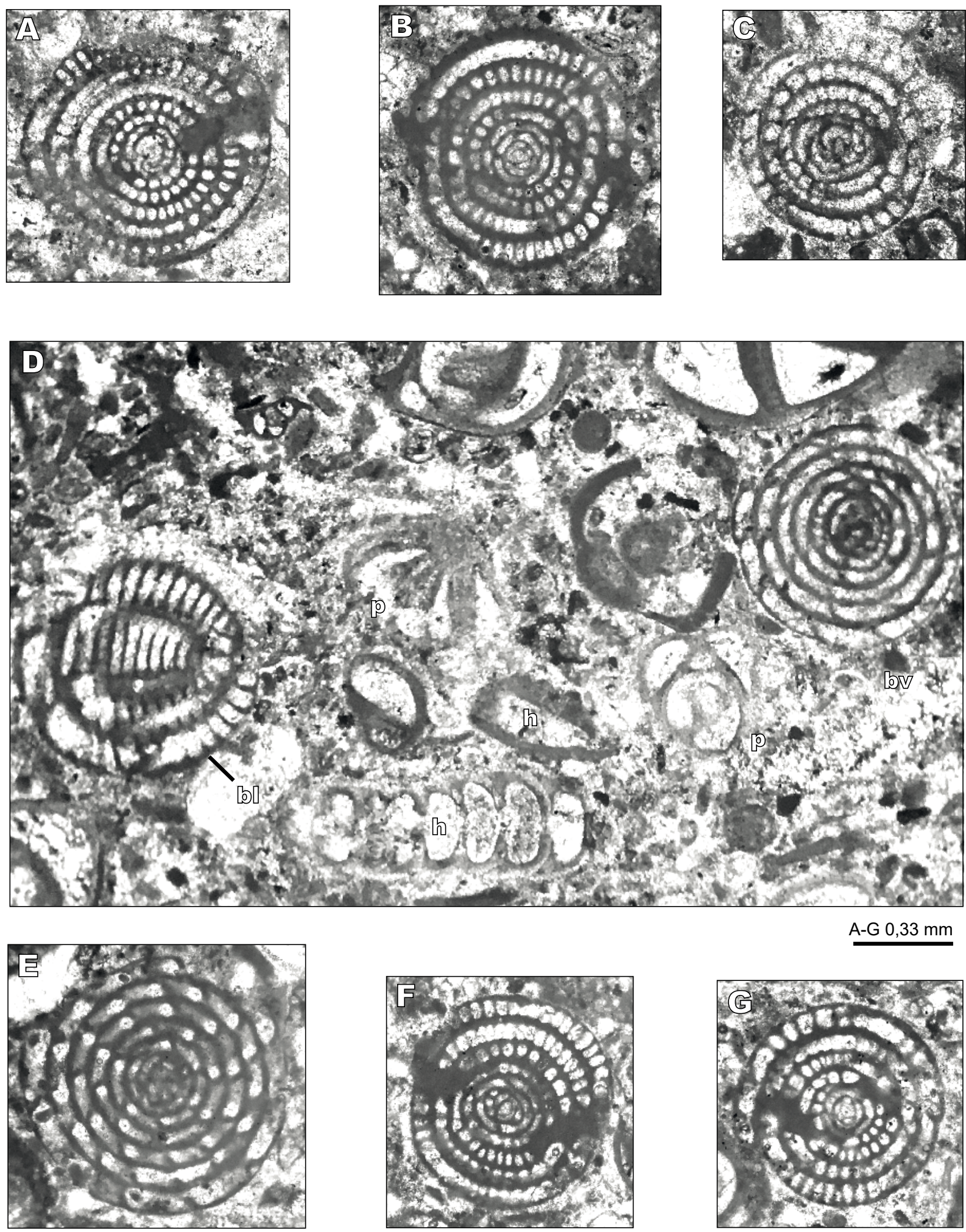

FIGURE 7. Borelis vonderschmitti and associated foraminifera. A) Axial section of Borelis vonderschmitti, showing tightly coiled whorls with small chamberlets (16-TA-23/3/3). B) Almost centered axial section of Borelis vonderschmitti with streptospiral early chambers and small chamberlets (16-TA-20b/4). C) Noncentered axial section of Borelis vonderschmitti (16-TA-20b/7). D) Tangential section of B. laxispira n. sp. (bl), almost equatorial section of $B$. vonderschmitti (bv), Haymanella sp. similar to H. elongata SIREL (h), peneroplids and miliolids (m) (16-TA-20b/10a). E) Almost equatorial section of Borelis vonderschmitti with narrow preseptal passage (KZ-2/2C/4). F) Axial section of Borelis vonderschmitti, showing very small protochonch followed by two rows of streptospiral chambers (16-TA-20b/3/1). G) Centered axial section of Borelis vonderschmitti with streptospiral chambers (16-TA-20b/2/1) 
Paratypes. Specimens KZ-2/5/5, KZ-2/5/2/1, 16-TA20b/10/1, 16-TA-20b/4/15, 16-TA-20b/3/3, 16-TA-20/2, 16-TA-20b/12, 16-TA-20/15, illustrated in Figure 8A-D, F-G, J-K and Figure 6B.

Material. 40 specimens from oriented axial, equatorial and tangential sections from the type locality.

Repository. Museum of the Department of Geological Engineering, University of Ankara, Turkey.

Type locality. Between the towns of Kiyıköy and Kömürköy, NE of the Kırklareli area, NE Thrace (Figs. 1C; $2 \mathrm{~A}$ ), at coordinates $35589742 \mathrm{E}, 4609277 \mathrm{~N}$, z: $50 \mathrm{~m}$.

Type level. Very shallow-water limestone of Priabonian age (SBZ 19-20), that occurs below shallow-water limestone with the early Oligocene species $N$. fichteli and $N$. vascus (SBZ 21).

Diagnosis. Spherical, rarely nautiloid test (Fig. 8D, G, L) with characteristically loosely coiled whorls displaying robust chamberlets (Fig. 8). The equatorial and axial diameters of the subspheric form range from $0,83 \mathrm{~mm}$ to $1,08 \mathrm{~mm}$ and the index of elongation varies between 0,85 to 0,96 . A very small proloculus $(0.05 \mathrm{~mm}$ in diameter) is followed by one or two rows of undivided streptospiral chambers (Figs. 8B, F-G; 6A). Later, the loosely divided whorl becomes planispiral and involute. In cross section, chamberlets are an upright oval and arranged tightly. The comparatively large chamberlets and thin septula are lined up from one chamber to the next (Figs. 6B; 7D; 8J-K). In equatorial section there are two streptospiral and 6-7 divided whorls, and the equatorial diameter measures 1 mm (Fig. 6A).

Remarks. There are two different Borelis species in the Priabonian of the Kazandere Member (Figs. 7A-G; 8AL) as shown by Schweighauser (1951, figs. 1-2, 4-5). One group of specimens, with a small test, tightly coiled whorls with small chamberlets and narrow preseptal passage (Fig. 7D-F), was described and figured by Schweighauser as $B$. vonderschmitti. The second group has been named B. laxispira n. sp. (Figs. 6A-B; 8A-L) based on the larger test, loosely coiled whorls and large chambers with robust chamberlets (Figs. 6A-B; 7D; 8A-L).

One tangential section of the species named Neoalveolina sp. by Schweighauser (1951, fig. 5) is identical to B. laxispira n.sp. (Figs. 6B; 8J-K) based on the loosely coiled whorls with large chamberlets.

The new species differs from $B$. vonderschmitti in its larger test and loosely coiled whorls with larger chamberlets. There are 5 whorls in an equatorial section of $B$. vonderschmitti, which measured $0.65 \mathrm{~mm}$ in diameter (Schweighauser, 1951, fig. 2), while with the same number of whorls, an equatorial section of the new species reached up to $0.92 \mathrm{~mm}$ in diameter (Fig. $8 \mathrm{~F}$ ). Furthermore, the new species has larger chambers than $B$ vonderschmitti, a preseptal passage and chamberlets.

Distribution. As for Boretis vonderschmitti.

Family: Rotaliidae EHRENBERG, 1839

Subfamily: Chapmaninidae tHALMANN, 1938

GENUS Chapmanina SILVESTRI, 1931

Type species: Chapmania gassinensis, SILVESTRI, 1905

Description. The test is conical with a hyaline calcareous wall. A bilocular-trilocular embryonic cone is followed by numerous uniserial discoidal chambers that enlarge rapidly in diameter as they are added. The marginal zone of the cone is divided by short vertical partitions that are arranged closely in a circumference and form almost elongated ovoid chamberlets between two successive rectilinear chambers (Fig. 6D). In the central part of the cone, the septa are folded and generate small chamberlets (Fig. 6C). The numerous pillars are distributed irregularly in the central part of the cone (Fig. 6C-D).

Remarks. This genus occurs from the Bartonian to Priabonian in Turkey.

Chapmanina gassinensis (SILVESTRI, 1905)

(Fig. 9A-K)

1905 Chapmania gassinensis (SILVESTRI), p. 235-276.

1931 Chapmanina gassinensis (SILVESTRI), p. 29-36.

1982 Chapmanina gassinensis (SILVESTRI), Sirel and Acar, pl. 4, figs. 10, 12, 13.

1985 Chapmanina gassinensis (SILVESTRI), Drobne et al., pl. 3 , fig. 8 .

1988 Chapmanina gassinensis (SILVESTRI), Sartoria and Ventruni, p. 186.

2010 Chapmanina gassinensis (SILVESTRI), Benedetti, p. 204, pl. II, fig. 7.

Description. The type species has a low conical test with hyaline calcareous wall. The apical angle is nearly $90^{\circ}$. The diameter of the cone base is $1.2-2.13 \mathrm{~mm}$ and the cone is $0.53-1.48 \mathrm{~mm}$ in height. The ratio of the cone height to the diameter of the cone base is $0.51-0.71$. The cross section of the marginal chamberlets is almost elongated ovoid in shape (Figs. 6C; 9A, E). There are 14 septa per $1 \mathrm{~mm}$ in the vertical length (Figs. 6C; 9A). The secondary chamberlets are generally semi-lunar in shape (Fig. 6C).

Distribution. Same as indicated in the description of $B$. vonderschmitti. Additionnally this species occurs in other localities of Turkey, such as the Priabonian limestone of 

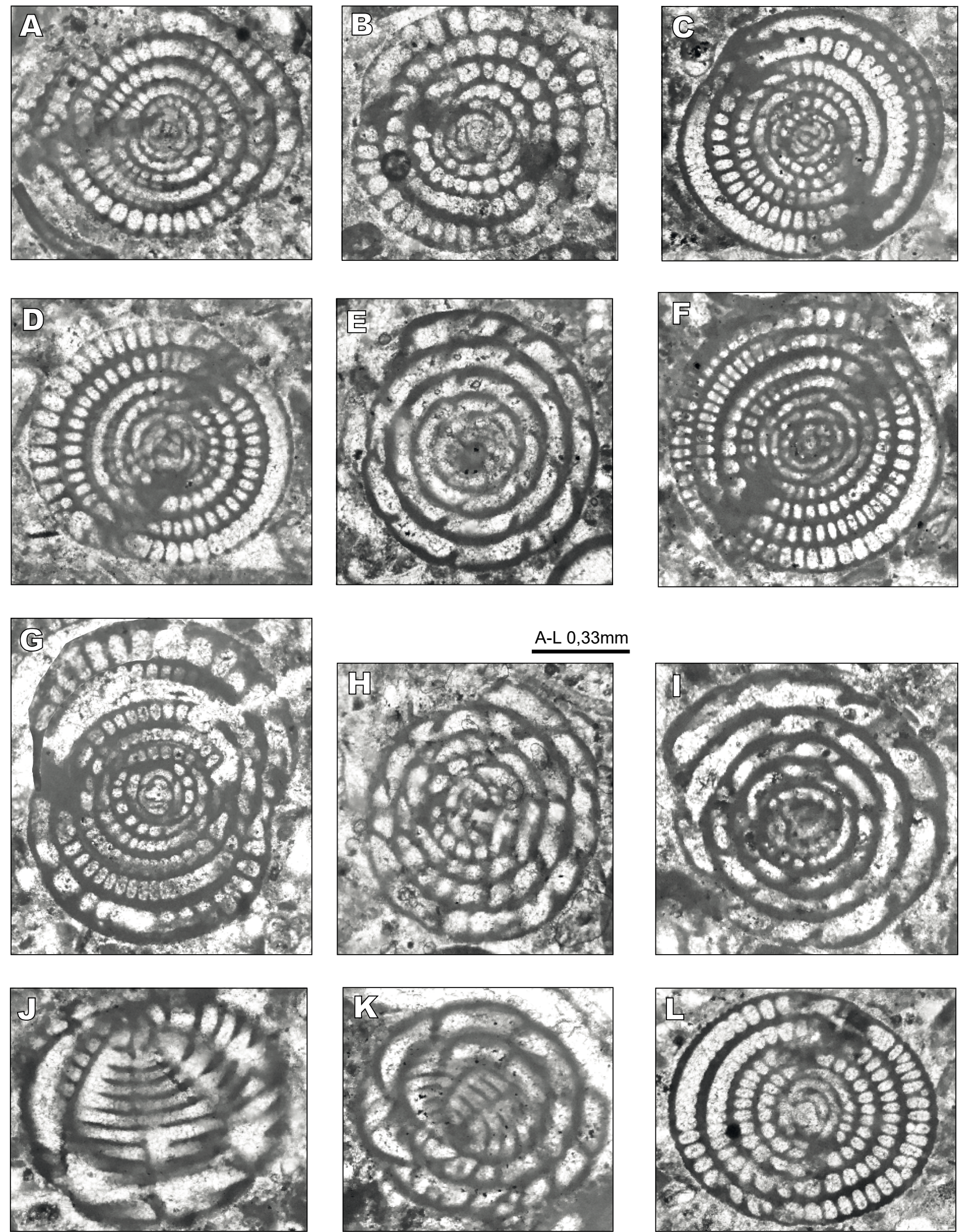

FIGURE 8. Borelis laxispira n.sp. A) Axial section, last whorl deformed (KZ-2/5/5). B) Axial section of small specimens (KZ-2/5/2/1). C) Axial section (16-TA-20b/10/1). D) Almost axial section (16-TA-20b/4/15). E) Non centered equatorial section, showing main apertural foramina (16-TA-20b/9/2). F) Axial section with embryonic chambers (16-TA-20b/3/3). G) Axial section of a nautiloid test deformed at the top side (16-TA-20/2); H) Non centered equatorial section (16-TA-20b/17a); I) Non centered equatorial section (16-TA-20b/12); J) Tangential section, showing continuous septula and chamberlets (16-TA-20b/12); K)Tangential section (16-TA-20/15); L) Axial section, holotype (KZ-2/2C/2). 

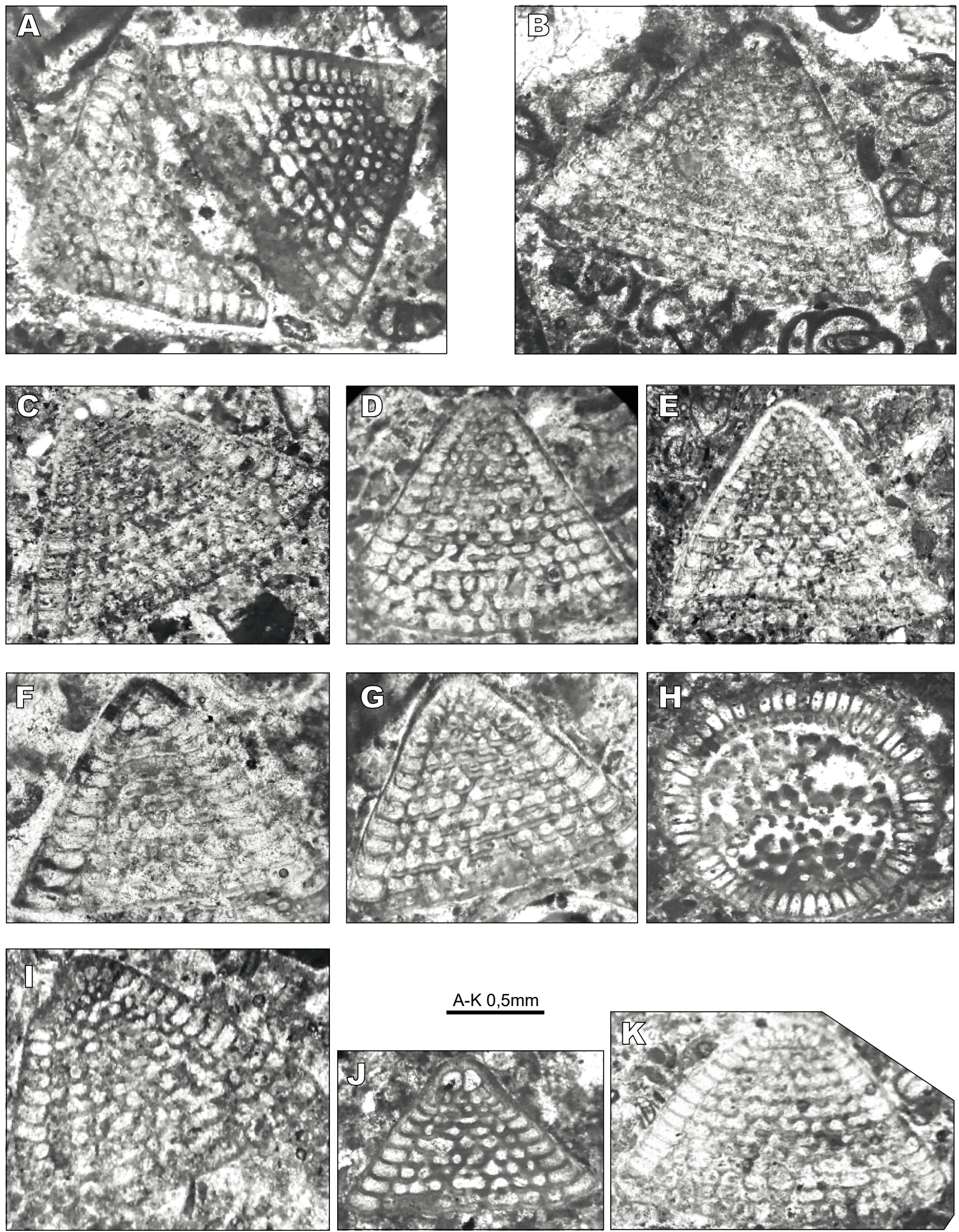

FIGURE 9. Chapmanina gassinensis. A) Almost vertical section (right) and incomplete vertical section (KZ-3/3/4); B) Vertical section, showing bilocular embyo, marginal and secondary chamberlets (KZ-2/5/2); C) Vertical section, showing bilocular embyo at the apex of cone (KZ-9/1/1); D) Non centered vertical section (16-TA- 23/3); E) Vertical section, showing small trochospiral chambers at the apex (KZ-3/3/2); F) Vertical section, showing trilocular embryonic chambers (16-TA-23/10); G) Almost vertical section (16-TA-23/4); H) Oblique horizotal section of Chapmanina sp. (probably $C$. gassinensis), showing vertical partitions, elongated ovoid marginal chambers, pillars and basal apertural foramina (16-TA-20b/5/1); I) Almost vertical section (KZ-2/2A/3); J) Vertical section of young specimens, showing bilocular embryonic chambers (16-TA20bA/1/1); K) Almost vertical section (16-TA-23/2/8). 
the Uluborlu area, South of Afyon, South-Central Turkey, associated with Nummulites fabianii retiatus (ROVEDA), Praebullalveolina afyonica SIREL AND ACAR, Chapmanina n.sp.?, Halkyardia minima (LIEBUS), Penarchaias sp., Gyroidinella magna (LE CALVEZ), Orbitolites sp., among others (Sirel and Acar, 1982; pl. 4, figs. 10, 12-14). In the Kovancilar section, East of Elazı $\breve{g}$, eastern Turkey, it occurs in the Bartonian limestone with Nummulites biedai SCHAUB, Asterigerina rotula (KAUFMANN), Fabiania cassis (OPPENHEIM), G. magna and orthophragminids, and in the Priabonian with $N$. fabianii (PREVER), N. boullei DE LA HARPE, $N$. garnieri DE LA HARPE, $N$. incrassatus DE LA HARPE, $N$. striatus (BRUGIERE), Silvestriella tetraedra (GÜMBEL) and others (Sirel, 2003, fig. 3). The species occurs also in the Priabonian limestone of the Arabil section, Arabil village, south Hatay, southern Turkey along with $N$. fabianii, $N$. cf. incrassatus, S. tetraedra, Rhabdorites malatyaensis (SIREL), A. rotula, F. cassis, G. magna and others (Sirel, 2003, fig. 2; Sirel, 2015, pl. 41, fig. 13).

\section{Chapmanina elongata sp. nOV. SIREL AND DEVECILER (Fig. 10A-G)}

1982 Chapmanina n.sp.?, Sirel and Acar, pl. 4, figs. 8, 9.

Origin of name. The name refers to the shape of the test, which is elongated.

Holotype. Specimen 16-TA-23C/8 (axial section) in Figure 10G.

Paratypes. Specimens 16-TA-20b/A/8/3, KZ-2/3/4, 16-TA-20b/A/6/1, KZ-3/1, 16-TA-06/3-1, illustrated in Figure 10B-F.

Material. 20 specimens from oriented vertical and tangential sections.

Repository. Museum of the Department of Geological Engineering, University of Ankara, Turkey.

Type locality. Between the towns of Kryıköy and Kömürköy, NE of the Kirklareli area, NE Thrace (Figs. 1C; 2A), at coordinates $35589742 \mathrm{E}, 4609277 \mathrm{~N}, \mathrm{z}: 50 \mathrm{~m}$.

Type level. A very shallow-water limestone of Priabonian age (SBZ 19-20), located below shallow-water limestone with $N$. fichteli and N. vascus (SBZ 21).

Diagnosis. The new species has a characteristic high conical test with a large ratio of the cone heigh to the base diameter (Fig. 10C, E). The diameter of the cone base ranges from 1.0 to $1.35 \mathrm{~mm}$, while its height ranges from 1.13 to $1.7 \mathrm{~mm}$. The ratio of the cone height to the diameter of the cone base is 1.1-1.7. The bilocular embryo and few trochospiral chambers are positioned at the apex (Fig. 10D-F).

Remarks. The new species differs from $C$. gassinensis in its high conical elongated test with smaller discoidal uniserial chambers. In addition, the ratio of the cone height to the diameter of the cone base is always larger than that of C. gassinensis. However, both species cannot be distinguished in their horizontal sections. Therefore, this species were determined as Chapmanina sp.

Distribution. Same as for B. vonderschmitti. This new species was first reported as Chapmanina n.sp.? from the Priabonian limestone of the Uluborlu area, South of Afyon, South-Central Turkey, where it occurred with $N$. fabianii retiatus, $P$. afyonica, $H$. minima, Penarchaias sp., $G$. magna, Orbitolites sp., and other species (Sirel and Acar, 1982; pl. 4, figs 8-9, 15).

Family: Chrysalidinidae NEAGU, 1968

GENUS Pfendericonus HOTTINGER AND DROBNE, 1980

Type species: Lituonella makarskae (VAN SOEST, 1942)

Description. This genus has a spherical-subspherical test with a small to large knob at the apex. Both the megalospheric and microspheric generations are followed by two trochospiral early chambers. The latter are connected by an intercameral basal foramen. The adult stage comprises large wedge-like chambers arranged in a uniserial pattern. Thick, incomplete spur-like septa are characteristic for the genus. The pillars and apertural foramina are distributed in the central region (Fig. 6E-F).

Remarks. This genus occurs from the early Eocene to early Oligocene.

Pfendericonus globulus sp. nov. SIREL AND DEVECILER (Fig. 11A-J)

1996 Pfendericonus sp. Sirel, p. 171, pl. 4, figs. 1-5, 13.

Origin of name. Referred to the globular megalospheric form.

Holotype. Specimen KZ-2/5/3/1 (vertical section) in Figure 11A.

Paratypes. Specimens 16-TA-5b/1, KZ-2/3/3, 16-TA23/2/13, 16-TA-23/11, 16-TA-23/1/1, 16-TA-23/3/5, 16-TA23/1, 16-TA-23/2-1 (Fig. 11B-J).

Material. 40 specimens from oriented vertical and horizontal sections.

Repository. Museum of the Department of Geological Engineering, University of Ankara, Turkey. 

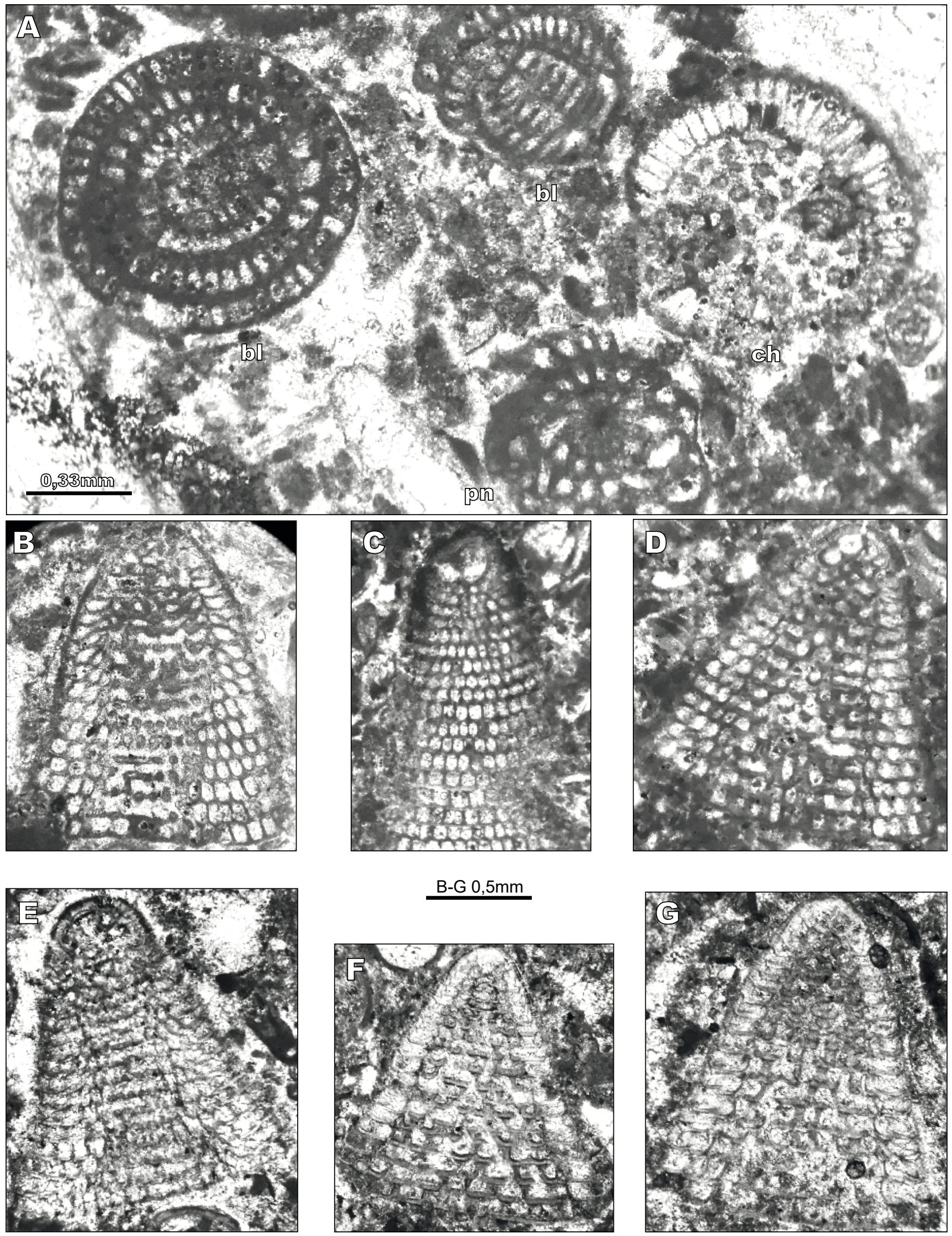

B-G $0,5 \mathrm{~mm}$
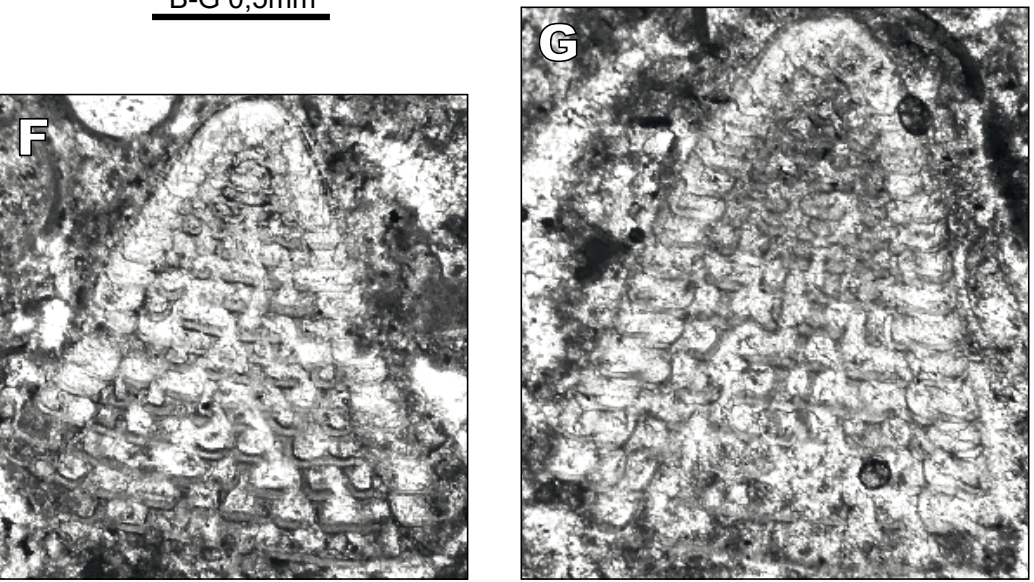

FIGURE 10: Chapmanina elonga n.sp. A) Limestone consists of subaxial and tangential sections of B. laxispira n.sp. (bl), a horizontal section of Chapmanina sp. (ch) and a peneroplid form (pn), (16-TA-22/7): B) Oblique subvertical section (16-TA-20b/A/8/3); C) Centered vertical section, inclined towards the periphery (KZ-2/3/4); D) Centered, slightly oblique vertical section (16-TA-20b/A/6/1); E) Oblque vertical section, showing trochospiral chambers at the apex (KZ-3/1); F) Almost vertical section, showing marginal and endoskeletal secondary chamberlets (16-TA-06/3-1 in Yalıköy); G) Almost vertical section, holotype, showing marginal and secondary chamberlets in the exo-endoskeletal area of the cone, respectively (16-TA-23C/8). 
Type locality. Between the towns of Kiyıköy and Kömürköy, NE of the Kirklareli area, NE Thrace, (Figs. 1C; $2 \mathrm{~A}$ ), at coordinates $35589742 \mathrm{E}, 4609277 \mathrm{~N}$, z: $50 \mathrm{~m}$.

Type level. Very shallow-water limestone of Priabonian age (SBZ 19-20).

Diagnose. The megalospheric generation has a characteristic globular-subglobular small test with agglutinated, canaliculate external wall (Fig. 11A-D). The diameter of the vertical section (parallel to the coiling axis) ranges from 1.0 to $1.2 \mathrm{~mm}$. The early globular megalosphere $(0.150-0.175 \mathrm{~mm}$ in diameter) is followed by three to four trochospiral early chambers, positioned at the apex of the globular test (Fig. 11A). The two neighbouring trochospiral early chambers are connected by intercameral foramina (Fig. 11A). The adult stage consists of large wedge-like chambers arranged in a uniserial pattern. The thick septa are characteristically incomplete and spur-like (Fig. 11AD). There are large apertural foramina and pillars in the central part of the test (Figs. 11J; 6F).

Large size and early chambers suggest that both megalospheric and microspheric generations occurred (Fig. 11F, H-I). The largest vertical diameter ranges from 1.4 to $2 \mathrm{~mm}$. The vertical section shows that the small microsphere is followed by four to five early trochospiral chambers (Fig. 11H). The adult stage is divided by spur-like shaped septa resulting in numerous wedge-like uniserial chambers as in the megalospheric form (Fig. 11F-I).

Remarks. Very shallow-water Pfendericonus was first described and figured as a new sub-genus of Chrysalidina D'ORBIGNY (type species Lituonella (Pfendericonus) macarskae VAN SOEST (Hottinger and Drobne, 1980, p. 13, 224). Later, Pfendericonus was elevated to generic status by Loeblich and Tappan (1987, p. 187). Due to the chamber arrangement in the early and adult stages, most authors share the view of Loeblich and Tappan (1987, p. 187).

The Priabonian species $P$. globulus sp. nov. differs from the late Cuisian species Chrysalidina (Pfendericonus) macarskae (VAN SOEST), as emended by Hottinger and Drobne (1980, p. 224), in its smaller and globular test (Figs. 6E, 11A-D). It differs from the Ilerdian species C. (Pfendericonus) kahleri HOTTINGER AND DROBNE in possessing a larger test and wedge-like chambers in the late ontogeny (Fig. 11A-I).

Distribution. The age of $P$. globulus sp. nov. is Priabonian (SBZ 19-20) in beds 16-TA-20 a, b to 16-TA-25A. But, as it can be seen in Figure 2A, samples 16-TA- 25B including this species were found at the same level as $N$. fichteli and $N$. vascus (SBZ 21). Otherwise, the five figures of Pfendericonus sp. provided by Sirel (1996, pl. IV, figs. 1-5) are identical to $P$. globulus sp. now. from the Kazandere Member. Both species were found as well in the veryshallow-water lower Oligocene limestone (SBZ 21) of the Diyarbakır area, southern Turkey (Sirel, 1996) associated with Praearchaias minutus SIREL, P. diyarbakirensis SIREL, Praerhapydionina delicata HENSON, P. huberi HENSON, Malatyna anatolica SIREL, Penarchaias glynnjonesi (HENSON), Austrotrillina asmariensis ADAMS, miliolids and peneroplids. The data support an early Oligocene age for P. globulus n.sp. in the reference section of the Kazandere Member (Fig. 2A).

Family: Meandropsinidae HENSON, 1948

Subfamily: Soritinae EHRENBERG, 1839

GENUS Orbitolites LAMARCK, 1801

Type species: Orbitolites complanatus LAMARCK, 1801

Orbitolites minimus (HENSON, 1950)

(Fig. 12A-G)

1950 Orbitolites complanatus link, var. minima HENSON, p. 58 , pl. 3 , fig. 1.

Description. The megalospheric generation has a small discoidal test with fineness characteristic of the internal structure as in Henson (1950a, p. 58) (Fig. 12A-C). The diameter of the test ranges from 3.3 to $3.65 \mathrm{~mm}$. A very large elongated ovoid megalosphere $(0.75-0.8 \mathrm{~mm}$ in diameter) is followed by a second chamber (Fig. 12E) and numerous cyclical chambers with chamberlets.

Remarks. Because of the presence of the small discoidal test with fine internal structure and very large megalosphere, the studied specimens (Fig. 12A-G) have been described and figured as O. minimus, although Priabonian species $O$. complanatus var. minima had been described and figured from inadequate equatorial section by Henson (1950a, p. 58, pl. 3, fig . 1).

Distribution. As given for B. vonderschmitti.

Family: Peneroplidae SCHULTZE, 1854

GENUS Coscinospira EHRENBERG, 1839 1839

Type species: Coscinospira hembrichii EHRENBERG,

\section{Coscinospira sp. \\ (Fig. 12H)}

Description. Elongated crosier-shaped test with imperforate, calcareous porcellaneous wall as in Coscinospira elongata SIREL AND ÖZGEN-ERDEM (Sirel et al., 2013, p.93). The diameter of the planispiral early stage is $0.275 \mathrm{~mm}$ and the length is $1.53 \mathrm{~mm}$. The small globular megalosphere $(0.075 \mathrm{~mm}$ in diameter $)$ is followed by 10 

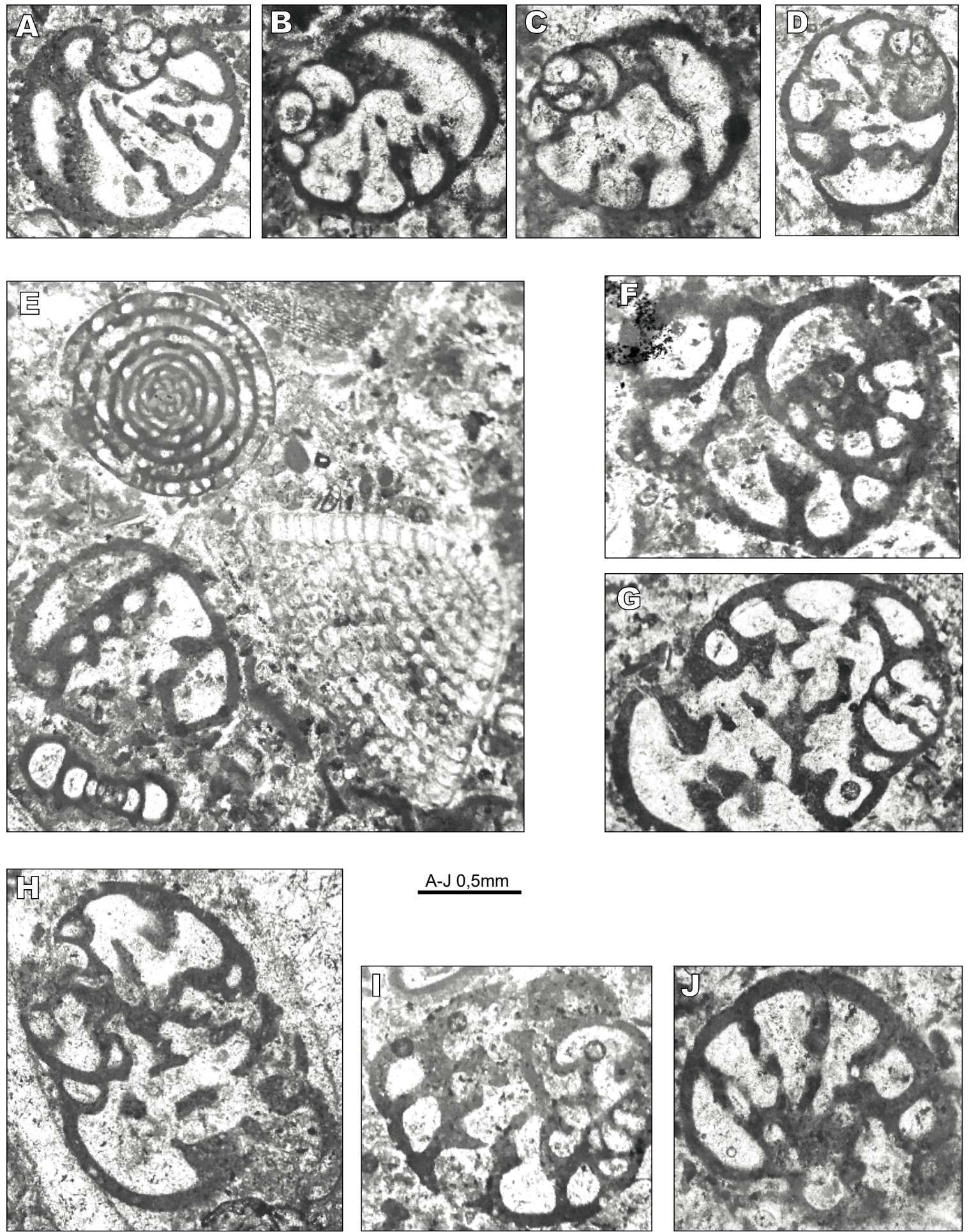

FIGURE 11. B. Pfendericonus globulus n.sp. A) Vertical section, showing large protoconch followed by small trochospiral early and wedge-like uniserial chambers with incomplete pillars, holotype, A form (KZ-2/5/3/1); B) Vertical section, A form (16-TA-5b/1); C) Vertical section, A form (KZ-2/3/3); D) Vertical section, A form (16-TA-23/2/13); E) Back-reef shoal limesone, showing oblique section of an A form, cuting apertural foramina (bottom left), oblique section of $B$. vonderschmitti (top left), almost vertical section of $C$. gassinensis (bottom right) and a miliolid (bottom left) (16-TA-23/2/8); F) Almost vertical section, B form, showing trochospiral early and uniserial adult chambers (16-TA-23/11); G) Oblique section, form B (16-TA-23/1); H) Vertical section of B form, showing small protochonch followed by trochospiral early and large shapeless uniserial chambers (16-TA-23/1/1); I) Subvertical section, B form (16-TA-23/3/5); J) Incomplete horizontal section, form A, showing basal apertural foramina, pillars and uniserial chambers at the periphery (16-TA-23/2-1). A, C-J Priabonian (SBZ 19-20), B early Oligocene (SBZ 21). All from the Kazandere Member of Soğucak Formation (Fig. 2A), in the vicinity of the Kıyıköy town, SE Kırklareli, Thrace. 
arcuate planispiral chambers of the early stage. Later, 11 dome-like uniserial chambers with cribrate aperture are arranged in an uncoiled stage (Fig. 12H).

Remark. Only one suitable specimen was observed in the studied samples, and it was not possible to determine the species. The elongated crosier-shaped Priabonian specimen (Fig. 12H) differs from the Oligocene C. elongata in its smaller test, and lesser number of planispiral and uniserial chambers. The interlocular spaces in the planspiral chambers are noteworthy (Fig. 12H).

Distribution. As given for B. vonderschmitti.

Family: Globotextularidae CUSHMAN, 1927

GENUS Globotextularia EIMER AND FICKERT, 1899

Type species: Haplophragmoides anceps BRADY, 1884

\section{Undetermined Globotextularid \\ (Fig. 12I-R)}

Description. High conical test with finely agglutinated wall. The early stage consists of more than six small trochospiral chambers (Fig. 12K). Later chambers immediately become triserial (Fig. 12N). Dome-like triserial chambers of the adult stage are devoid of endoexoskeletal subdivision. The apertural foramen is positioned at the middle part of the three dome-like adult chambers (Figs. 12 I-J, M).

Remark. The Holocene genus Globotextularia sp. EIMER AND FICKERT (type species: Haplophragmoides anceps BRADY, 1884) is poorly known. It was described and figured in detail from the Gulf of Mexico by Loeblich and Tappan (1985). The specimens described and figured here resemble $G$. anceps (BRADY) in the dome-like triserial adult chambers and large basal foramen (Figs. 12J, M-N). However, G. anceps illustrated by Loeblich and Tappan (1987, p. 143, pl. 150, fig. 5) has five large trochospiral chambers in the three whorls of the early stage instead of the small numerous chambers at the apex of the Kazandere specimens (Fig. 12L).

Distribution. As given for B. vonderschmitti.

\section{Nummulites fichteli MICHELOTTI, 1841}

(Fig. 13A-C)

1841 Nummulites fichteli MICHELOTTI, p. 44, pl. 3, fig. 7.93 1850 Nummulites intermedia D' ARCHIAC, p. 416, pl. 9, figs. 23, 24.

1853 Nummulites intermedia D' ARCHIAC, d'Archiac and Haime, p. 99, pl. 3, figs. 3a-d, 4a-f.

1853 Nummulites garansianus JOLY AND LEYMERIE, d'Archiac and Haime, p. 101, pl. 3, figs. 6a, 7a-g.
1911 Nummulites intermedius D’ ARCHIAC, Boussac, p. 84, pl. 1, figs. 4, 5, pl. 2, fig. 12, pl. 4, fig.3.

1970 Nummulites fichteli MichelotTI, Roveda, p. 320, pl. 23, figs. 3, 4, 6.

1975 Nummulites fichteli MiCHELOTTI, Sirel et al., s. 178. lev. 1 , şek. 1-9.

1976 Nummulites fichteli MICHELOTTI, Sirel and Gündüz, s. 157, lev. 2, şek. 1-6, 9.

1976 Nummulites intermedius D' ARCHIAC, Sirel and Gündüz, s. 156, lev. 1, şek. 19.

1981 Nummulites fichteli MichelOTTI, Schaub, p. 128, pl. 50, figs. 5-18; tb. $15 \mathrm{k}$,t.

2015 Nummulites fichteli MichelOTTI, Sirel, pl. 50, figs. $1-5$.

2018 Nummulites fichteli MICHELOTTI, Sirel and Deveciler, p. 92 , pl. 39,40 .

Description. The megalospheric form has a small and inflated lenticular test with rounded-pointed peripheral margin (Fig. 13A-B). The diameter of the test ranges from 3.1 to $3.6 \mathrm{~mm}$ and the thickness $1.25-1.5 \mathrm{~mm}$. The rectangular or subrectangular septal filaments form a meshwork on the test surface. Weakly developed granules totally merge to form a regular reticulation. The equatorial sections clearly show that the spire interval increases gradually from the first whorl to the last one (Fig. 13C). The globular megalosphere is followed by subrectangular chambers that line up in 5-6 whorls. The width of the subrectangular chambers is always greater than the height (Fig. 13A). There are 6-7 whorls in an equatorial section measuring $3.4 \mathrm{~mm}$ in diameter (Fig. 13C).

Distribution. N. fichteli occurs in the lower Oligocene shallow-water limestone, located at the top of the Kazandere Member with $N$. vascus, O. complanata and an amphisteginid. It also occurs in the early Oligocene (SBZ 21) of the Dolhandere, East of Kirklareli, central Thrace with N. vascus and Operculina (Sirel and Gündüz, 1976). Furthermore, it occurs in the Rupelian-lower Chattian of eastern and southern Turkey (Sirel, 2003, figs. 2-12).

\section{Nummulites vascus JOLY AND LEYMERIE, 1848}

(Fig. 13D-J)

1848 Nummulites vascus JOLY AND LEYMERIE, p. 38,67, pl. 1, figs. 15-17; pl. 2, fig.7.

1911 Nummulites vascus JOLY AND LEYMERIE, Boussac, p. 35, pl. III, figs. 17, 18.

1952 Nummulites vascus JOLY AND LEYMERIE, Grimsdale, pl. 25, figs. 1,2.

1975 Nummulites vascus JOLY AND LEYMERIE, Sirel et al., s. 178, lev. II, ssek. 1-9.

1976 Nummulites vascus JOLY AND LEYMERIE, Sirel and Gündüz, s. 157, lev. II, şek. 7,8; lev. III, şek. 1-9.

1981 Nummulites vascus JOLY AND LEYMERIE, Schaub, p. 

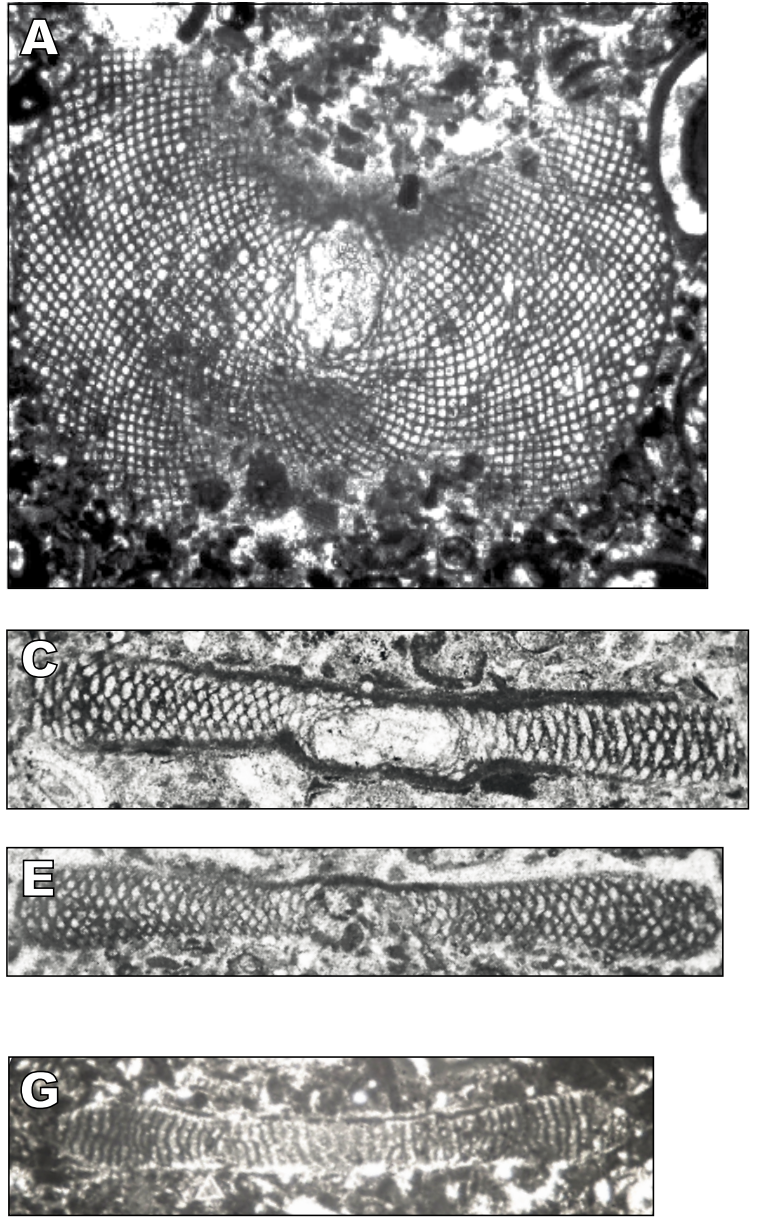

$\mathrm{H}-\mathrm{R} 0,5 \mathrm{~mm}$
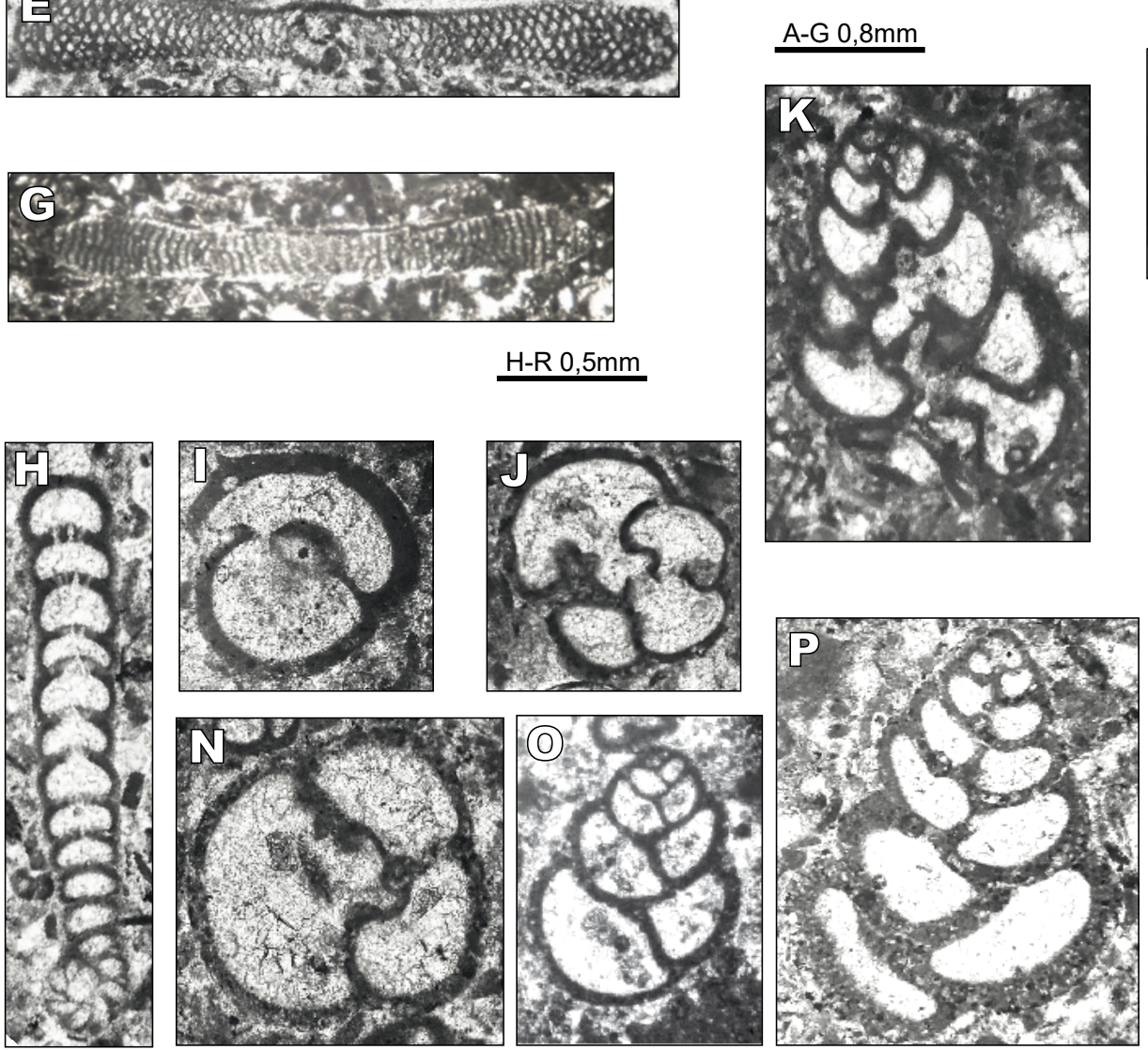
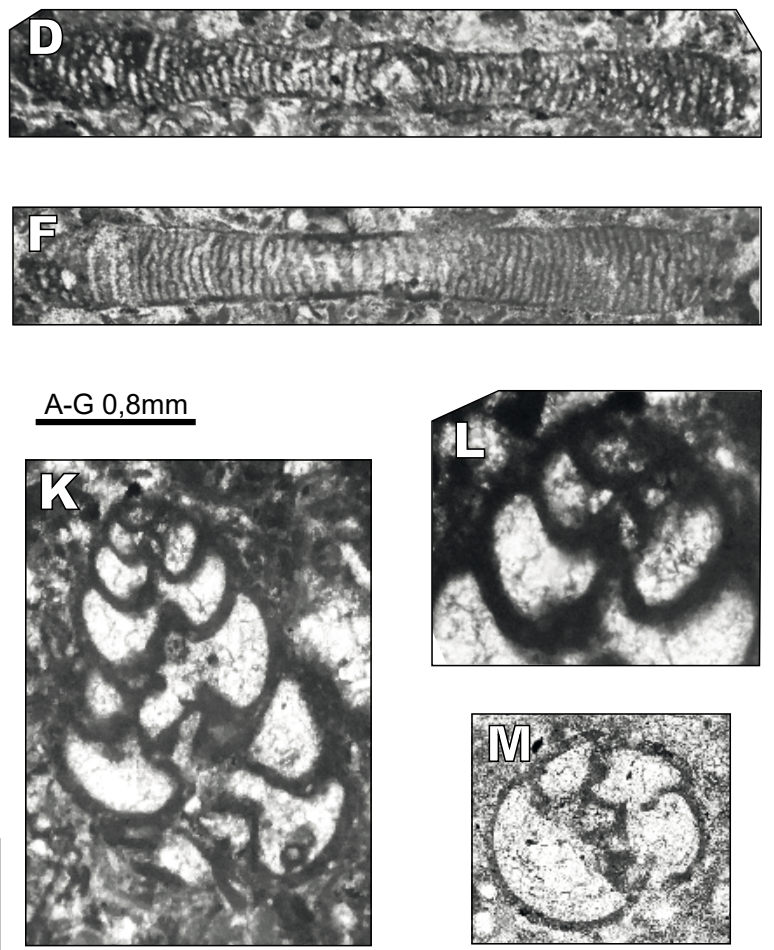

FIGURE 12. Orbitolites minimus: A) Incomplete equatorial section (16-TA-20a/1/3); B) Oblique section inclined to the equatorial plane (KZ-3/2/1); C) Axial section (KZ- /5/2/4); D) Axial section (16-TA-23/2/1); E) Axial section (KZ-2/2C/1); F) Subaxial section (16-TA-23/1/3); G) Subaxial section (16-TA-20b/3/2). Coscinospira sp.: H) Longitudinal section, showing planispiral early and uniserial adult chambers with cribrate apertural openings (KZ-2/5/3/2). Undetermined globotextularid: I) Horizontal section cutting two chambers with foramen (16-TA-20b/8/5); J) Almost horizontal section (KZ-2/2A72); K) Vertical section, showing trochospiral early chambers (16-TA-20b/7/4); L) Trochospiral chambers, enlarged from Figure 11; M) Oblique horizontal section, showing basal foramen (16-TA-20b8/4); N) Horizontal section, the cavity of the apertural foramen at the middle of the triserial chambers (KZ-7/1); O) Subvertical section (16-TA-23/9); P) Vertical section with agglutinated wall (16-TA-23/3/2); R) Vertical section (KZ2/1/1). All from the Kazandere Member of Soğucak Formation (Fig. 2A) in the vicinity of the Kıyıköy town, SE Kırklareli, Thrace. 

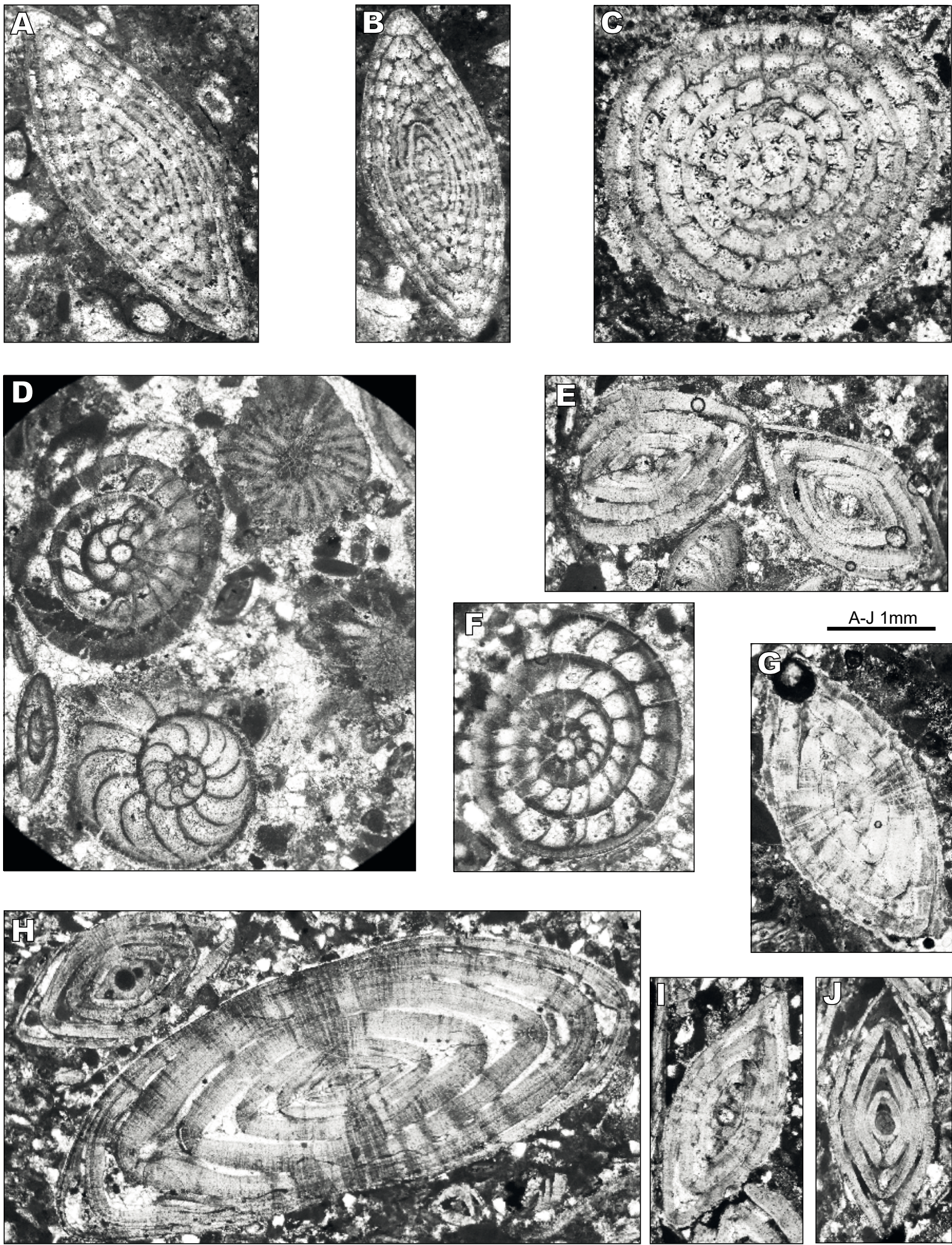

FIGURE 13. Nummulites fichteli: A) Almost axial section (16-TA-17B/2/1); B) Axial section (16-TA-17B/2/2-3); C) Equatorial section (16-TA$17 \mathrm{~B} / 5 / 1-3)$. Nummulites vascus: D) Equatorial section of $A$ form (mid left), external view of $A$ form (top right), equatorial section of $O$. complanata, A form (mid bottom) (16-TA-17A/4/6-1); E) Axial sections of two specimens (16-TA-17A/4/3-2); F) Equatorial section, A form (16-TA$17 \mathrm{~A} / 4 / 4 \mathrm{a}-2) ; \mathrm{G})$ Axial section, A form (16-TA-17B/1/7-2); H) Fore-reef shoal limestone showing an axial section of an $A$ form bottom right and an axial section of a B form (mid) (16-TA-17A/2/2-2); I) Axial section, A form (16-TA-17A/1/1-2); J) Axial section, A form (16-TA-17A7/2/3). All from the Kazandere Member of Soğucak Formation (Fig. 2A), in the vicinity of the Kıyıköy town, SE Kırklareli, Thrace. 
123, pl. 53, figs. 1-6.

2003 Nummulites vascus JOLY AND LEYMERIE, Sirel, p. 292, pl. II, figs. 4,5 .

2015 Nummulites vascus JOLY AND LEYMERIE, Sirel, pl. 41, figs. 10,11; pl. 50, figs. 6,7.

2018 Nummulites vascus JOLY AND LEYMERIE, Sirel and Deveciler, p. 97, pl. 41, figs. 1-15.

Description. The microspheric form has an inflated lenticular test with rounded periphery (Fig. 13H). The average diameter of the test is $6 \mathrm{~mm}$ and the thickness is $2.25 \mathrm{~mm}$. Strongly curved septal filaments cover the lateral sides of the test.

The megalospheric form has a small inflated lenticular test with a slightly rounded periphery (Fig. 13E-G). The diameter of the test ranges from 2.1 to $3.2 \mathrm{~mm}$ and the thickness is $1.0-1.5 \mathrm{~mm}$. The surface of the test is ornamented with a small central knob and slightly curved thick septal filaments (Fig. 13D). The globular megalosphere (0.200$0.250 \mathrm{~mm}$ in diameter) is followed by small subrectangular chambers that are lined up in 4 whorls (Fig. 13F). The spire interval increases gradually from the megalosphere to the last whorl. Thin septa are curved backward.

Distribution. N. vascus occurs in the lower Oligocene shallow-water limestone located at the top of the Kazandere Member with, N. fichteli, O. complanata and an amphisteginid. It occurs in the Rupelian-lower Chattian of eastern and southern Turkey (Sirel, 2003, figs. 2-3, 5-7, 9, 12). N. vascus is found in the Chattian limestone of the Sogukpinar sequence together with numerous foraminiferal species (Sirel and Işık, 2011, fig. 2).

\section{CONCLUSIONS}

Throughout the Mediterranean region, very shallowwater (inner ramp) marine deposits with porcellaneous foraminifera (particularly alveolinids) are virtually absent in the Priabonian. An exception to this situation are the very shallow-water limestone facies with mainly Borelis species, such as that of the Kazandere Member from the Thrace region (Turkey), newly defined herein, which contains well preserved and abundant $B$. vonderschimiti, B. laxispira $\mathrm{n}$. sp., C. gassinensis, C. elongata n. sp., P. globulus n.sp, $O$. minimus and Coscinospira sp. This Priabonian sequence with $B$. vonderschimitti and $B$. laxispira n. sp. occurs just below the Oligocene limestone with $N$. fichteli, which allows the precise definition of the Eocene-Oligocene boundary in the study area.

In addition, B.vonderschimiti, B. laxispira n.sp. are significant to understand the evolution of the Alveolinidae EHRENBERG in the region. At the end of Bartonian, all over the Mediterranean region, large tectonic movements (especially orogenic) resulted in major regresions, which lead to the disappearance of very shallow species of Alveolina D' ORBIGNY. However, the alveolinid genus Borelis and particularly $B$. vonderschimitti and B. laxispira n.sp. remained, thus the alveolinids carried on in the Tethyan realm.

\section{ACKNOWLEDGMENTS}

This study was supported by the Ankara University BAP with project 15B0443003. We are grateful to Baki Varol for his constructive and detailed review an early draft of the manuscript. We also thank to Mehmet Önal (İnönü Univ. of Malatya) and Meltem Dölen (MTA-Ankara) for their contributions in the field work. We acknowledge an anonymous reviewer and Dr. Antonino Briguglio for valuable suggestions during peer review, and the managing editor Dr. Carles Martín-Closas for improvements of the manuscript during the editorial process.

\section{REFERENCES}

Akartuna, M., 1953. Çatalca-Karacaköy bölgesinin jeolojisi (The geology of Çatalca-Karacaköy vicinity) (In Turkish). İstanbul Üniversitesi Fen Fakültesi Monografileri, 13, 183-204.

Boussac, J., 1911. Études Paléontologiques sur le Nummulitique Alpin. Paris, Mémoires Pour Servir à l'Explication de la Carte Géologique Détaillée de France, 9, 1-437.

Brady, H.B., 1884. Report on the foraminifera dredged by H.M.S. Challenger, during the years 1873-1876. In: Thomson, W.C., Murray, J. (ed.). Report of the scientific result of the voyage of the H.M.S. Challenger during the years 1873-1876. Zoology, 9(22), 1-814.

Cahuzac, B., Poignant, A., 1997. Essai de biozonation de l'OligoMiocène dans les basins européens à l'aide des grands foraminifères néritiques. Bulletin de la Société Géologique de France, 168, 155-169.

Çağlayan, M.A., Yurtsever, A., 1998. 1/100 000 ölçekli Türkiye Jeoloji haritaları, no: 20, 21, 22, 23 (The 1/100 000 scaled geological maps of Turkey, number: 20, 21, 22, 23)(In Turkish). Jeoloji Etüdleri Dairesi, 99pp.

Cushman, J.A., 1927. An outline of a re-classification of the foraminifera. Contributions from the Cushman Laboratory for Foraminifera Research, 3, 1-105.

D’Archiac, A.D., 1850. Description des fossiles du groupe nummulititique recueillis par M.S.-P. Pratt et M. J. Delbos aux environs de Bayonne et de Dax. Mémoires de la Société Géologique de France, 2, 397-456.

D’Archiac, A., Haime, J., 1853. Description des animaux fossiles du groupe Nummulitique de L'Inde. Paris, Gide et Baudry Libraires-Editeurs, 11, 1-156.

Dac1, A., 1951. Étude paléontologique du Nummulitique entre Küçükçekmece-Çatalca II. Istanbul Üniversitesi Fen Fakültesi Mecmuası, XVI, Seri B, Tom XVI, 2, 207-246. 
Deveciler, A., 2010. The first appearance of the Bartonian benthic foraminifera at the Çayraz Section (north of Haymana, south of Ankara, central Turkey). Yerbilimleri, 31(3), 191-203.

Deveciler, A., 2014. Description of larger benthic foraminifera from the Bartonian of Yakacik-Memlik region (N Ankara, Central Turkey). Yerbilimleri, 35(2), 137-150.

Drobne, K., Pavlovec, R., 1979. Microfosiline karakteristike starejsega Paleogena na zahodnem obrobju Panonskega bazena. In: Drobne, F. (ed.). Zbornikradova IV, Znan. Zagreb, Skup za naftu JAZU, 155-172.

Drobne, K., Pavlovec, R., Drobne, F., Cimerman, F., Šikić, L., 1985. Some larger Foraminifera from the upper Eocene and Oligocene beds in north Slovenia. Geoloski Glasnik Herald Geological Bulletin Geologique, 28, 77-117.

Ehrenberg, C.G., 1839. Über die Bilgdung der Kreidenfelsen und des Kreidemergels durch unsichtbare organismen. Physikalische Abhandlungen der Königlichen Akademie der Wissenschaften zu Berlin, 59-147.

Eimer, G.H.T., Fickert, C., 1899. Die Artbildung und Verwandtschaft bei den Foraminiferen: Entwurf einer natürlichen Eintheilung derselben. Zeitschrift für Wissenschaftliche Zoologie, 65, 599-708.

von Fichtel, L., Von Moll, J.P.C., 1798. Testacea microscopica, aliaque minuta ex generibus Argonauta et Nautilus, ad naturam picta et descripta. Vienna, Camesianische Buchhandlung, $1-123$.

Görür, N., Okay, A., 1996. A fore-arc origin for the Thrace Basin, NW Turkey. Geologische Rundschau, 85, 662-668.

Grimsdale, T.F., 1952. Cretaceous and Tertiary foraminifera from the Middle East. Bulletin of the British Museum (Natura History)-Geology, 1(8), 221-248.

Henson, FR.S., 1948. Larger imperforate Foraminifera of south-western Asia. Families Lituolidae, Orbitolinidae and Meandropsinidae. British Museum (Natural History), 127pp.

Henson, FR.S., 1950a. Cretaceous and Tertiary reef formations and associated sediments in Middle East. Bulletin of the American Association of Petroleum Geologists, 34(2), 215-238.

Henson, FR.S., 1950b. Middle Eastern Tertiary Peneroplidae (Foraminifera) with remarks on the phylogeny and taxonomy of the family. Wakefield (England), The Yorkshire Printing Co. Limited, 70pp.

Hottinger, L., 1963. Les Alvéolines paléogènes. Example d'un genre polyphylétique. In: Von Koenigswald, E. (ed.). Evolutionary trends in Foraminifera. Elsevier, 298-314.

Hottinger, L., 1974. Alveolinids, Cretaceous-Tertiary larger foraminifera. ESSO Production Research-European Laboratories, 1-84.

Hottinger, L., Drobne, K., 1980. Early Tertiary imperforate foraminifera. Slovenska Akademija Znanosti in Umetnosti, Clasis IV Historia Naturalis, Dissertations, 22(3), 187-276.

Joly, N., Leymerie A., 1848. Memoire sur les Nummulites considereés zoologiquement et géologiquement. Toulouse, Mémoires de l'Académie des Sciences, 4(3), 1-70.

Lamarck, J.B., 1801. Système des animaux sans vertebres. Paris, the Author, 432pp.
Less, G, Özcan, E., Okay, A., 2011. Stratigraphy and larger foraminifera of the Middle Eocene to lower Oligocene shallow-marine units in the northern and eastern parts of the Thrace Basin, NW Turkey. Turkish Journal of Earth Sciences, 20, 793-845.

Loeblich, A., Tappan, H., 1985. Some new and redefined genera and families of agglutinated foraminifera II. Journal of Foraminiferal Research, 15, 175-212.

Loeblich, A., Tappan, H., 1987. Foraminiferal genera and their classificarion. New York, Von Nostrant Reinhold, 970pp.

Michelotti, G., 1841. Saggio storico dei Rizopodi caratterictici dei terreni supracretacei. Modena, Memorie di Matematica e di Fisica della Società Italiana delle Scienze, 22, 253-302.

de Montfort, P.D., 1808. Conchyliologie systématique et classification méthodique des coquilles. Paris, Schœll Libraire, 1, 1-87.

Neagu, T., 1968. Study of the Miliolidaceae in the lower Cretaceous (Barremian) of southern Dobrogea. Paris, Travaux du Museum d'Histoire Naturelle, 8, 563-572.

Okay, A.I., Özcan, E., Cavazza, W., Okay, N, Less, G.Y., 2010. Basement types, lower Eocene series, upper Eocene olistostromes and the initiation of the southern Thrace basin. Turkish Journal of Earth Sciences, 19, 1-25.

Okay, A.I., Özcan, E., Hakyemez, A., Siyako, M., Sunal, G., Kylander-Klarl, A., 2019. The Thrace Basin and the Black Sea: the Eocene-Oligocene marine connection. Geological Magazine, 156(1), 39-61.

Okay, A.I., Simmons, M.D., Özcan, E., Starkie, S., Bidgood, M.D., Kylander-Clarke, A.R.C., 2020. Eocene-Oligocene succession at Kiyıköy (Midye) on the Black Sea coast in Thrace. Turkish Journal of Earth Sciences, 29, 139-153.

Özcan, E., Less, G., Jovane, L., Catanzariti, R., Frontalini, F, Coccioni, R., Giorgioni, M., Rodelli, D., Rego, E.S., Kayğıll, S., Rostami, M.A., 2019, Integrated biostratigraphy of the middle to upper Eocene Kırkgeçit formation (Baskil section, Elazı $\breve{g}$, eastern Turkey): larger benthic foraminiferal perspective. Mediterranean Geoscience Reviews, 1, 55-90.

Özcan, E., Özcan, Z., Okay, A.I., Akbayram, K., Hakyemez, A., 2020. The Ypresian to Lutetian marine record in NW Turkey: a revised biostratigraphy and chronostratigraphy and implications for Eocene paleogeography. Turkish Journal of Earth Sciences, 29, 1-27.

Reiss, Z., Hottinger, L., 1984. The Gulf of Aqaba, Ecological Micropaleontology. New York, Tokyo, Heidelberg, Berlin, Springer-Verlag, 354pp.

Roveda, V., 1970. Revision of the Nummulites (Foraminiferida) of the N. fabianii-fichteli group. Rivista Italiana di Paleontologia e Stratigrafia, 76(2), 235-324.

Sartorio, D., Ventruni, S., 1988. Southern Tethys Biofacies. Agip S.p.A. (Donato Milanese), 166pp.

Schaub, H., 1981. Nummulites et assilines de la Tethys Paléogene: taxonomie, phylogènese et biostratigraphie. Mémoires Suisses de Paléontologie, 104-105-106, 236pp.

Schultze, M.S., 1854. Überden Organismus der Polythalamien (Foraminiferen), nebst Bermerkungen über die Rhizopoden im Allgemeinen. Leipzig, Wilhelm Engelmann, 68pp. 
Schweighauser, J., 1951. Ein Vorkommen von Neoalveolina aus dem Vicentinisschen Obereocaen. Eclogae Geologicae Helvetiae, 44, 465-469.

Serra-Kiel, J., Hottinger, L., Caus, E., Drobne, K., Ferrandez, C., Jauhri, A.K., Less, G., Pavlovec, R., Pignatti, J., Samso, J.M., Schaub, H., Sirel, E., Strougo, A., Tambareau, Y., Tosquella, J., Zakrevskaya, E., 1998. Larger foraminiferal biostratigraphy of the Tethyan Paleocene and Eocene. Bulletin de la Société Géologique de France, 169, 281-299.

Silvestri, A., 1905. Sul Dictyoconus aegytppiensis (Chapman). Roma, Atti della Pontificia Accademia Romana dei Nuovi Lincei, 58, 129-131.

Silvestri, A., 1931. Sul genere Chapmanina e sulla Alveolina maiellana n.sp. Bolletino della Società Geologica Italiana, 50, 63-73.

Sirel, E., Metin, S., Sözeri, B., 1975. Palu (KD Elazı̆̆) denizel Oligosen'in stratigrafisi ve mikropaleontolojisi (The stratigraphy and the micropaleontology of the marine Oligoce of Palu (NE of Elazı $\breve{g}$ )) (In Turkish with English abstract). Türkiye Jeoloji Kurumu Bülteni, 18, 176-180.

Sirel, E., Gündüz, H., 1976. Kırklareli yöresi (kuzey Trakya) denizel Oligosen'nin stratigrafisi ve Nummulites türleri (The stratigraphy and the species of Nummulites of the marine Oligocene of Kirklareli region (North of Thrace)) (In Turkish with English abstract). Türkiye Jeoloji Kurumu Bülteni, 19, 155-158.

Sirel, E., Acar, Ş., 1982. Praebullalveolina, a new foraminiferal genus from the upper Eocene Afyon and Çanakkale regions (W of Turkey). Eclogae Geologicae Helvetiae, 75(3), 821-839.

Sirel, E., 1996. Praearchaias, a new soritid genus (Foraminiferida) and its Oligocene shallow water foraminiferal assemblage from the Diyarbakır region (SE Turkey). Geologica Romana, 32, 167-181.

Sirel, E., 2003. Foraminiferal description and biostratigraphy of the Bartonian, Priabonian and Oligocene shallow-water sediments of the southern and eastern Turkey. Revue de Paléobiologie, 22(1), 269-339.

Siyako, M., 2006. Trakya havzası Tersiyer kaya birimleri (The rock units of the Thrace Basin) (In Turkish). In: Altıner, D. (ed.). Trakya bölgesi litostratigrafi birimleri, Ankara, M.T.A. Stratigrafi Komitesi Litostratigrafi Birimleri Serisi, 2, 43-77.
Sirel, E., Işık, U., 2011. Marasella n.gen. (Miogypsinidae, Foraminiferida) and re-description of Risananeiza Boukhary, Kuss and Abdelraouf, 2008 from the late Chattian of the Maras Region (S of Turkey). Revue de Paléobiologie, 30(1), 31-43.

Sirel, E., Özgen-Erdem, N., Kangal, Ö., 2013. Systematic and biostratigraphy of Oligocene (Rupelian-early Chattian) foraminifera from lagoonal-very shallow water limestone in the eastern Sivas Basin (central Turkey). Geologia Croatica, 66(2), 83-109.

Sirel, E., 2015. Reference sections and key localities of the Paleocene stages and Discussion on the C-T, P-E and E-O Boundaries by the Very Shallow-Shallow Water Foraminifera in Turkey. Ankara, Ankara Üniversitesi Yayınları, 170pp.

Sirel, E., Deveciler, A., 2018. Description and some revision of Ranikothalia Caudri, Nummulites Lamarck and Assilina D'Orbigny species from Thanetian of Turkey. Ankara, Ankara Üniversitesi Yayınları,182pp.

van Soest, J., 1942. Geologie und Paleontologie des zentralen Biokovo (Dalmatien). Geographische en Geologische Mededeelingen, Physiographisch-Geologische Reeks, 3, 1-42.

Şengör, A.M.C., Yilmaz, Y., 1981. Tethyan evolution of Turkey: a plate tectonic approach. Tectonophysics, 75(3/4), 181-241.

Thalmann, H.E, 1938. Bibliography and index to new genera, species and varieties of foraminifera for the year 1935. Jounal of Paleontology, 12, 177-208.

Turgut, S., Türkaslan, M., Perinçek, D., 1991. Evolution of the Thrace sedimentary basin and its hydrocarbon prospectivity. In: Spencer, A.M. (ed.). Generation, Accumulation and Production of Hydrocarbon in Europe. Hydrocarbon European Association of Petroleum Science, 1 (Special Publication), 415-437.

Varol, B., Baykal, M., Ayyıldız, T., 2009. Sedimentologicalstratigraphical evaluation of Tertiary carbonates (Soğucak Formation) of Thrace Basin (Bozcaada -Kiyiköy). Mineral Resources Exploration Bulletin, 139, 1-15.

Yücel, A.O., Özcan, E., Erbil, Ü., 2020. Latest Priabonian larger benthic foraminiferal assemblages at the demise of the Soğucak Carbonate Platform (Thrace Basin and Black Sea shelf, NW Turkey): implications fort the shallow marine biostratigraphy. Turkish Journal of Earth Sciences, 29, 85-114.

Manuscript received August 2019;

revision accepted June 2020;

published Online September 2020. 